\author{
Antoni Remesar \\ University of Barcelona \\ Department of Arts and Heritage \\ The POLIS Research Centre \\ at University of Barcelona \\ Pau Gargallo 4 \\ 08028 Barcelona \\ aremesar@ub.edu
}

\author{
Bibiana Crespo-Martin \\ University of Barcelona \\ Department of Arts and Heritage \\ Pau Gargallo 4 \\ 08028 Barcelona \\ bbcrespo@ub.edu
}

\title{
THE WHITE CENTER. A FIRST STEP OF THE CIVIC REMEMBRANCE SYSTEM IN BON PASTOR (BARCELONA)
}

\begin{abstract}
Following the development in 2011 of the Mural of Remembrance in Baró de Viver (Barcelona) the adjacent district of Bon Pastor, showed interest in a symbolic and artistic element of similar characteristics. However, from the beginning, Bon Pastor neighbours expressed the idea that writing their remembrance should not be performed on a linear support, but should be distributed by the territory. The research team of the Polis Research Centre started a participatory process (not yet completed) within the framework of cooperation agreements between the Centre, the Neighbourhood association and the local authorities of the Sant Andreu district. At the same time, the subject of this "memory space system" became a topic to be developed by one of the, interdisciplinary and international, teams of students of the Master in Urban Design, Universitat de Barcelona. This article presents the progress made.
\end{abstract}

Keywords:

Civic participation, urban design, public art, urban governance, urban decorum

\section{FROM TERRITORIAL TO URBAN COHESION. BARÓ DE VIVER - BON PASTOR (BARCELONA)}

Urban growth and recent transformations brought us a new context of cities, introducing new urban characteristics and dynamics, such as: (1) scattered cities, polycentric and discontinuous, forming peri-urban areas (where currently occur the highest rates of urban growth and real estate development) highly dependent from the city centre; and (2) shrinking urban consolidated areas either due to the decrease and aging population or to the loss of activities/functions causing vacancy of space in the city centre. 
Transformations such as these ones just mentioned originate ambivalent new urban realities which represent a new variety of typologies and characteristics which are important in nowadays context of territorial dynamics, having direct impacts on urban life. The emergence of these urban contexts also brings us some problems such as, lack of connectivity; fragmentation issues; segregation and marginalization; lack of functions and user's diversity; or loss of social and economic dynamics.

Although these fragilities have different types and levels of impact depending on the urban reality where they occur, we can ask whether the fragility of the social and economic structures is caused by the lack of cohesion in the morphological and functional structure of these territories.

Recently we introduced the concept of Urban Cohesion, ${ }^{1}$ as an attempt of describing a set of factors with direct influence on urban development. The fundaments of this concept come from the notion of Territorial Cohesion, introduced by the Commission of European Communities in 2004 trying to enable the transition from the definition of strategies to the formulation of specific intervention measures which can manage these new urban realities. Urban cohesion evolves issues related to the physical form of the city and its planning processes, but also to its socio-economic and socio-cultural factors, including those linked to urban identity.

Public space plays a key role in the conformation of spatial structures that support urban cohesion, being a crucial factor in the processes of appropriation and symbolization of the city as it has been pointed out by Borja, Valera or Brandão. ${ }^{2}$ If public space is the agent that furthers cohesion in these territories, urban cohesion can be the base concept to guide the interventions in these new urban realities.

Since the late nineteenth century, with the beginning of the European city metropolitan growth, urbanization processes start facing a constant dialectics between centre and periphery, a phenomenon quite well known since the work by Lefebvre. ${ }^{3}$ The need to provide minimum housing conditions for thousands of emigrants moving from countryside to the city, looking for better opportunities, generates its strong urbanization growth, which occur uninterruptedly until

\footnotetext{
${ }^{1}$ Ana Júlia Pinto, Coesão urbana: o papel das redes de espaço público (Barcelona: CR POLIS. Universitat de Barcelona, 2015, http://hdl.handle.net/10803/320186); Ana Júlia Pinto and Antoni Remesar, "Public Space Networks as a Support for Urban Diversity," Open House International, 37 (2012), 15-24.

${ }^{2}$ Jordi Borja, Luces y sombras del urbanismo de Barcelona (Barcelona: Universitat Oberta de Catalunya, 2009); Sergi Valera, "Identidad y significado del espacio urbano desde una perspectiva psicosocioambiental. Nuevo espacio público y nuevos retos sociales," Arquitectonics 19-20 (2010), 125-136; Pedro Brandão, La imagen de la ciudad. Estrategias de Identidad y Comunicación (Barcelona: Publicacions i Edicions de la Universitat de Barcelona, 2011).

${ }^{3}$ Henry Lefebvre, La revolución urbana (Madrid: Alianza Editorial, 1973).
} 
the end of the twentieth century. Consequently, the new modes for producing space that start with the process of de-industrialization in the decades of 1970 1980, generate a new city model, now based on the dialectics between extensive occupation and intense occupation of the territory. Processes that we can call sprawling city vs compact cities. These transformations processes brought us scattered, discontinuous, fragmented, suburban realities. On the other hand, further recent transformations of central urban areas, brought us new realities of shrinking urban consolidated areas, caused both by aging population and by loss of functions, bringing about vacancy of space in the city centre.

In fact, as Brandão noted in her doctoral dissertation, we face ambivalent urban realities, which are generating a set of new urban typologies, different from the canonical city, ${ }^{4}$ having important impacts on urban life. ${ }^{5}$ Many of these new problems are strongly connected to the lack of cohesion on the urban fabric. If cohesion can be semantically understood as the action or effect of meeting or joining things together or the matter which forms them, our aim is to advance in what urban cohesion is. The concept of cohesion intends to harmoniously respond to the challenge of inequality readjustment. Àngels Martinez Castells, following Musgrave, states, that this readjustment has to be done through the functions, of allocation, stabilization and redistribution of resources, functions which seek to offset the failures of the free market. On one hand the stabilizing functions increasingly escape the control of national states to a supranational control (EU, IMF), especially in these times of crisis. And on the other hand, the theory of resource redistribution "explains that as greater are the income differences to correct, more easy it should be to achieve that balance, at a centralized level." 6 This fact that could explain the current trend to transfer these responsibilities to supranational bodies (e. g. with the founds FEDER and FEOGA), but raises an EU structural contradiction between the neo-liberal structural thinking and the regional cohesion policies ideology.

The allocating resource function becomes the basis of the principle of subsidiarity. According to this principle, a particular government task can only be transferred to a higher level of public administration structure, when the lower level is not able to assume it. Analyzing the experience of Ley de Barrios de Catalunya (2004), Hernando and Remesar state that: "Subsidiarity has to be

\footnotetext{
${ }^{4}$ We take this concept from Portas, The concept refers to the type of organization of the City that has characterized the westen urbanization development since the mid-nineteenth century and that has in the "street" the structuring structure that organizes and defines the city. See Nuno Portas, Os tempos das formas, Vol. I. A cidade feita e refeita (Guimarães: Universidade do Minho, 2005).

${ }^{5}$ Ana Luísa Gonçalves Brandão Estêvão, A incerteza no proceso urbano. A produção do espaço na Margem Sul do Estuário do Tejo (Barcelona: Universitat de Barcelona, 2015), http://tdx. cat/handle/10803/320178.

${ }^{6}$ Àngels Martínez Castells, "De l'exercici de la sobirania nacional al principi de subsidiarietat," in La qüestió nacional, un debat obert, ed. Marcelo Céspedes (Barcelona: Fundació Pere Ardiaca, 1996), 55.
} 
shown as the projects have to be executed with the closest territorial proximity possible, and at the level of administration which is going to be most effective." "7 Therefore, the generation of territorial cohesion aims to:

(1) respond to the diverse social, economic and cultural realities and needs of these neighbourhoods, considering the different levels or stages of execution of the activity; (2) stimulate projects that foster cooperation and vertical and horizontal transversality in order to achieve integrated, complementary and coherent policy implementation; (3) provide local authorities with the tools that enable them to satisfy the needs of their populations: (a) in a collective way depending on target groups; (b) in an individual way, designing programmes to help people into employment and improve their qualifications; (4) facilitate strategic and sectorial planning tools to guarantee better results; (5) foster the creation of inclusive political public agendas in the fields of labour, employment, local development and urban regeneration. ${ }^{8}$

From the urban territorial perspective, the regular use of territorial cohesion concept faces a problem of scale, in trying to operate not at a large territorial scale (e. g. 1:25.000 - 1:10.000 scale) but at specific territory (scale 1:5000 - 1:500). At these scales, we have to deal with the "physicality/materiality" of the territory. The urban project scale is made of houses, streets, squares, parks, rivers, forests... So, we can talk of public space as the spatial system (the specific scenarios) in which inequalities, physical fragmentations, discontinuities and concrete inaccessibility occur. A lack of mobility and accessibility schemes and solutions restrict the way people move within the city and limit access to the uses, services and activities as Ascher pointed out. ${ }^{9}$ Concerning natural structures, we are facing "irreparable damage"; and regarding urban life (social and economic issues) some processes of appropriation and identity, of concentration/de-concentration of services, have suffered considerable weakening.

The situation can be summarized in an increased growing of problems linked to cohesion, mostly related to: (1) a lack of physical connectivity mainly generated by the phenomena of spatial and functional segregation; (2) hyper-spatialization and economic hyper-specialisation of the urban structure; and (3) problems of social exclusion, marginalisation and loss of identity.

In fact, the current logic of urban space production frequently results on spatial segregation, based in facts such as: (1) remoteness from the centre; (2) isolation of the area or neighbourhood because the transport network does not reach there; (3) deficits in urbanization, from the lack of basic services (electricity, sewerage, health and even education), to a chronic shortage of equipment in a minimum design of public space (lack of asphalted streets,

\footnotetext{
${ }^{7}$ Mateo Hernando and Nemo A. Remesar, "The 'Employment in the Neighbourhoods' project: A local economic development experience in Catalonia," Local Economy 6 (2011), 584.

${ }^{8}$ Ibidem, 585.

${ }^{9}$ François Ascher, Los Nuevos Principios Del Urbanismo (Madrid: Alianza Editorial, 2001).
} 
of lighting, of public spaces including qualified green space, of symbolic elements of identity reference); (4) Reduction of urban functions in the neighbourhood just to one: being a bedroom suburb. ${ }^{10}$

Thus, contrary to some implicit assumptions in current urban analyses that are prioritizing fragmentation and discontinuity, we use the concept of urban cohesion from the perspective of formal coherence and spatial continuity following the principles already pointed out by Borja in his definition of public space. Therefore, the existence of a logic behind the production of public space, supported by the dimensions of visibility, continuity and accessibility, ${ }^{11}$ becomes the "level zero" - paraphrasing Barthes - of urban cohesion analysis. "2 Furthermore, the quality of public space, as a support for urban life and cohesive element of the territory, also depends on other urban cohesion issues bounded with the territory productive activity. ${ }^{13}$ Furthermore, in its capacity to become "space of representation," 14 able to promote identitary dimensions of citizens and facilitate positive territorial inclusion in the image of the city as it was pointed out by Brandão and Valera. ${ }^{15}$

\section{BARÓ DE VIVER - BON PASTOR. TWO NEIGHBOURHOODS IN BARCELONA}

Following Castells, the areas of expansion of Spanish cities pursue three different patterns of growth that "even today define the structure of the residential peripheries of most Spanish cities." All these expansion areas are

\footnotetext{
${ }^{10}$ To see the role of these principles in the area of study you can consult: Antoni Remesar and Ángela Lúzia, Nas Margens / En los Márgenes. Bairro Amarelo, Baró de Viver (Barcelona: Universitat de Barcelona, 2013); Antoni Remesar, Xavier Salas, Samuel Padilla and Dánae Esparza, "Inclusion and empowerment in public art and urban design," On the W@terfront 24 (2012); Antoni Remesar, Xavier Salas and Tomeu Vidal, "Urban Governance and Creative Participation in Public Space and Public Art," in The Art of Urban Design in Urban Regeneration, ed. Antoni Remesar (Barcelona: Edicions de la Universitat de Barcelona, 2016).

${ }^{11}$ The analysis of these topics can be followed in: Jordi Borja and Martínez Zaida Muxí, L'espai públic: ciutat i ciutadanía (Barcelona: Diputació de Barcelona, 2001); Jordi Borja, Estado y Ciudad. Descentralización Política y Participación (Barcelona: PPU. Promociones y Publicaciones Universitarias, 1988); Jordi Borja, Luces y sombras del urbanismo de Barcelona (Barcelona: Universitat Oberta de Catalunya, 2009).

${ }^{12}$ Roland Barthes, El grado cero de la escritura (Buenos Aires: Jorge Álvarez,1967).

${ }^{13}$ Nemo A. Remesar, "Employment, Social Cohesion and Territory. Integrating labour market policies into urban regeneration processes in Catalonia: The Employment in the Neighbourhoods case study," in The Art of Urban Design in Urban Regeneration, ed. Antoni Remesar (Barcelona: Edicions de la Universitat de Barcelona), 27-61.

${ }^{14}$ Henry Lefebvre, La revolución.

${ }^{15}$ Pedro Brandão, La imagen; Pedro Brandão, O Sentido da Cidade. Ensaios sobre o mito da Imagem como Arquitectura (Lisboa: Livros Horizonte, 2011); Sergi Valera, "Identidad y significado."
} 
peripheral to the city centres and the wealthy districts of the city. "These peripheries constituted the cultural medium through which urban social movements developed." 16 The three patterns of development are: (1) suburban developments, (2) so-called marginal areas of urbanization located in the extreme periphery of the city and illegally built, (3) new housing projects, or "poligonos de viviendas" (housing states).

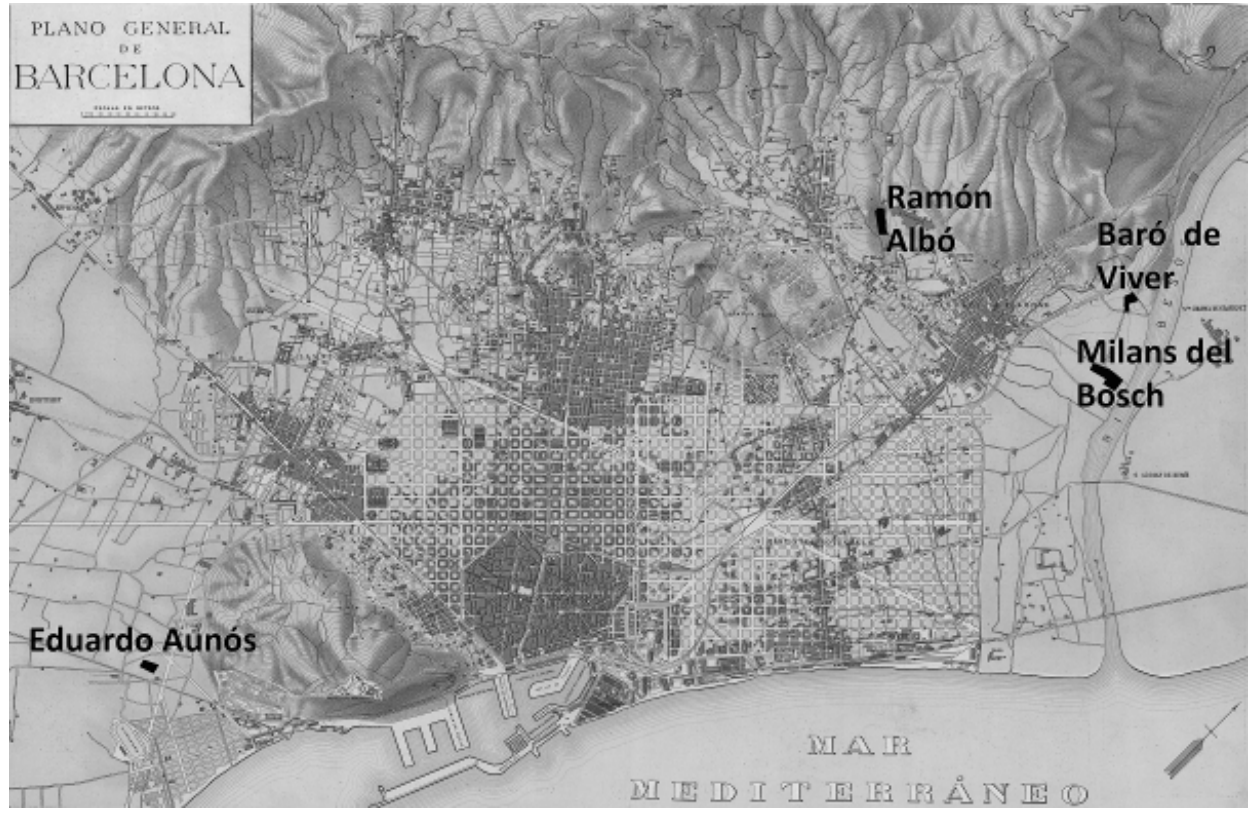

Fig. 1. The four groups of housing states known as "casas baratas" (1929). They start of a new territorial logic that will have its development during the Franco regime. It can be seen: the expulsion of the working and popular housing to the periphery of the city. ${ }^{17}$ Source: Institut Cartogràfic de Catalunya.

According to Solà-Morales there are three processes involved in urban growth: parcelling $(\mathrm{P})$, urbanization $(\mathrm{U})$ and building $(\mathrm{B}) .{ }^{18}$ One of the characteristics of a housing state (poligono) is that the three processes occur together

\footnotetext{
${ }^{16}$ Manuel Castells, La cuestión Urbana (México: Siglo XXI Editores, 1972).

${ }^{17}$ To understand better this process you can consult: Miquel Domingo, and Ferran Sagarra, Barcelona. Les Cases Barates (Barcelona: Ajuntament de Barcelona, 1999); Amador Ferrer, Els Polígons de Barcelona (Barcelona: Edicions de la UPC, 1996); Borja M. Iglesias, and José Luis Oyón. Las barracas y la infravivienda en la construcción de Barcelona,1914-1950. Barracas. La Barcelona informal del siglo XX (Barcelona: Museu d'Història de Barcelona (MUHBA), 2010, http://docplayer.es/6991499-Las-barracas-y-la-infravivienda-en-la-construccion-de-barcelona-19141950-barracas-la-barcelona-informal-del-siglo-xx.html); María Mercedes Tatjer Mir and Cristina Larrea-Killinger, Barraques. La Barcelona Informal del segle XX (Barcelona: Ajuntament de Barcelona, 2010).

${ }^{18}$ Manuel Solà-Morales, Les formes del creixement urbà (Barcelona: Edicions UPC, 1993).
} 
$(\mathrm{P}+\mathrm{U}+\mathrm{B})$. A relatively large site is divided into plots that will contain buildings. At the same time the site is urbanized, although, in Spanish practice since 1920s to now, this urbanization is in deficit, being reduced to the minimum. The first housing states in Barcelona, were those driven by the Municipal Institute of Housing of the ending 1920s. According to Salas this Institute developed "four groups low cost housing for rent (...) in order to accommodate the slum dwellers evicted from Montjuïc and immigrants arriving in Barcelona at this time on the occasion of the works of the International Exhibition of 1929.",19

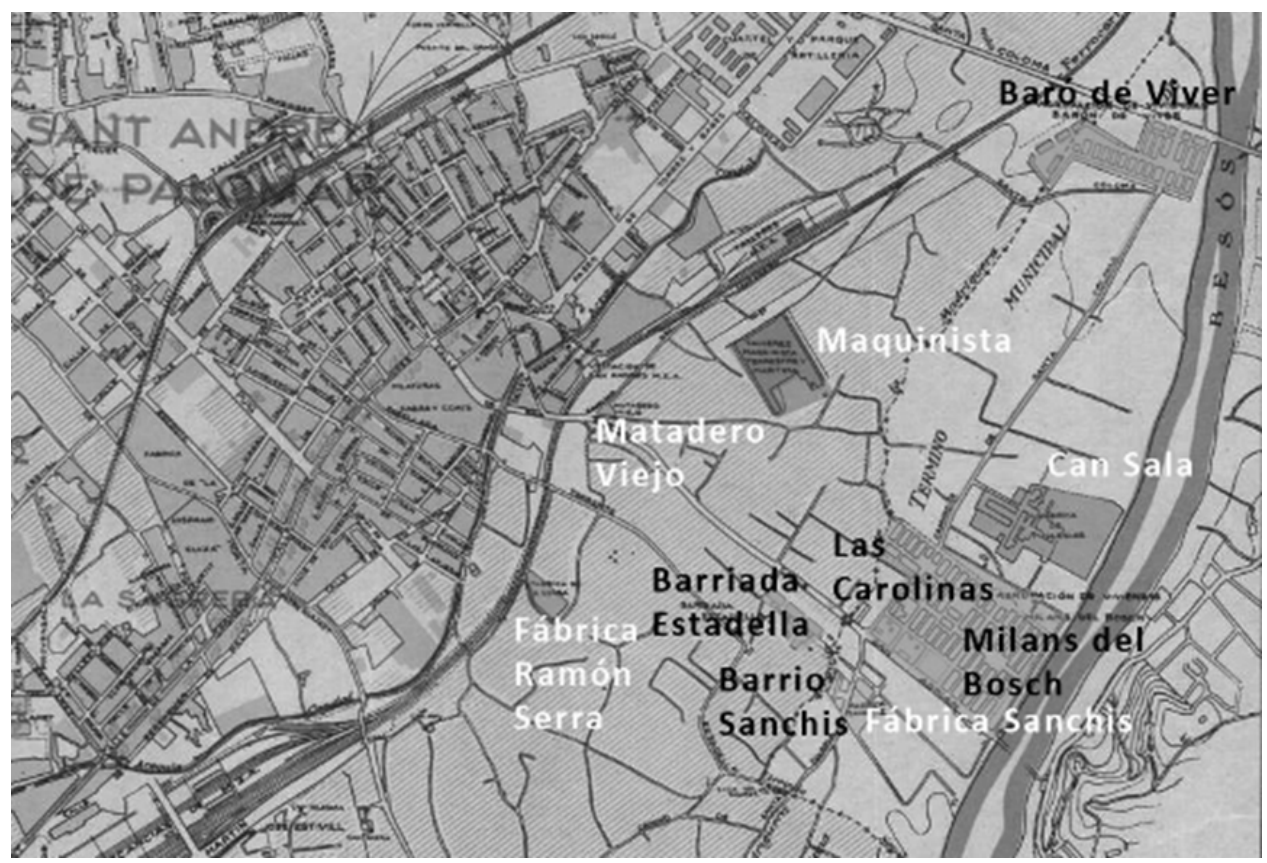

Fig. 2. In white big industrial states around the Bon Pastor. In black, the group and the small neighbourhoods, 1930's. Source: Institut Cartogràfic de Catalunya.

The two groups that interest us in this work, Baró de Viver and Milans del Bosch, had the peculiarity of being in the municipality of Santa Coloma and not in Barcelona until 1944, when a decree of annexation integrated both groups in the city limits. Moreover, the group Milans del Bosch (now called Bon Pastor) was sited in a relatively urbanized zone. The small neighbourhoods of "La Estadella," "Las Carolinas" and "Sanchis" shared territory with the largest group.

\footnotetext{
${ }^{19}$ Xavier Salas, "Bon Pastor (Barcelona). Un territorio en construcción," On the W@terfront 43 (2016), 9-10.
} 


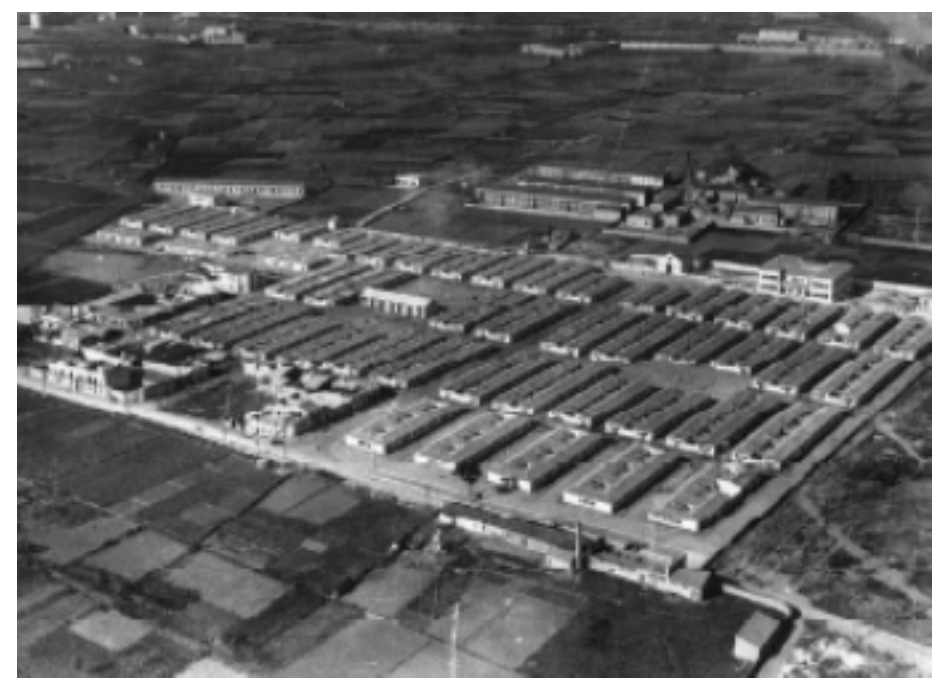

Fig. 3. Aerial view of Baró de Viver, circa 1930. Source: Institut Cartogràfic de Catalunya.

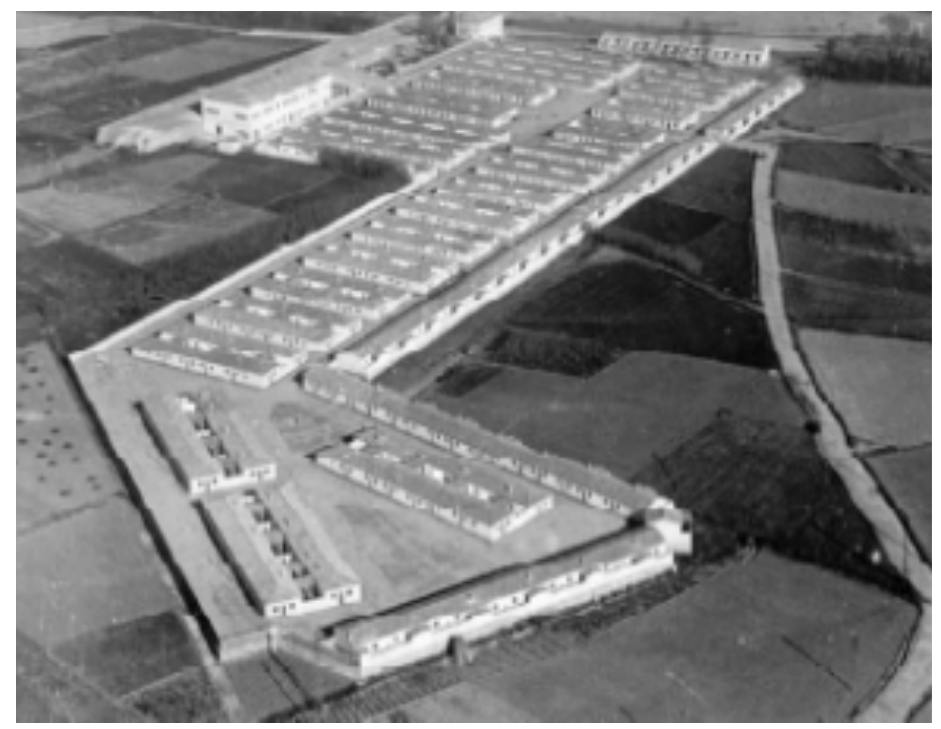

Fig. 4. Aerial view of Bon Pastor, circa 1930. Source: Institut Cartogràfic de Catalunya.

The two neighbourhoods share origin. The smaller one is called Baró de Viver and the larger one Bon Pastor, although it first was called Milans del Bosch. The name Barò de Viver referred to the Mayor of Barcelona at the time while Milans del Bosch was in honour of General and Civil Governor of the province. All this happened during the dictatorship of General Primo de Rivera. The two groups share a long life isolated from the rest of the city. They were marginalized suburbs. 
The White Center...

\begin{tabular}{|c|c|c|c|c|c|}
\hline & & Barcelona & Sant Andreu & Bon Pastor & Barò de Viver \\
\hline Residents & & 1.614 .090 & 146.539 & 12.760 & 2.438 \\
\hline $\mathrm{Km} 2$ & & 102,2 & 6,6 & 1,9 & 0,2 \\
\hline $\mathrm{Hab} / \mathrm{Km} 2$ & & 15.800 & $\Delta 22.321$ & V 6.780 & $\nabla_{10.600}$ \\
\hline \multirow{2}{*}{$\begin{array}{l}\text { Population by nationality (\%) } \\
\text { Población por nacionalidad }\end{array}$} & National/ Nacionales & 83,3 & 88,4 & 88,0 & 90,0 \\
\hline & Foreigners / Extranjeros & 16,7 & 11,6 & 12,0 & 10,0 \\
\hline Birth rate/ 1.000 hab. & Tasa Natalidad/ 1.000 hab. & 8,2 & A $\quad 8,9$ & A 9,7 & $\nabla 7,5$ \\
\hline \% College Graduates & \% Tituladossuperiores & 27,5 & $\nabla 18,9$ & $\nabla_{11,2}$ & $\nabla_{5,6}$ \\
\hline Ageing Index & $\begin{array}{l}\text { Indice de } \\
\text { sobreenvejecimiento }\end{array}$ & 54,8 & 52,6 & $\nabla 1,4$ & $\triangle 54,4$ \\
\hline $\begin{array}{l}\text { Population over } 65 \text { living } \\
\text { alone (\%) }\end{array}$ & $\begin{array}{l}\text { Población de más de } 65 \\
\text { años que vive sola (\%) }\end{array}$ & 25,7 & 24,3 & 21,5 & 28,9 \\
\hline $\begin{array}{l}\text { Household disposable } \\
\text { income } x \text { inhabitant }\end{array}$ & $\begin{array}{l}\text { Renta familiar disponiblex } \\
\text { habitante }(\mathrm{BCN}=100)\end{array}$ & 100,0 & $\nabla 72,9$ & $\nabla 67,3$ & $\nabla \mathbf{5 2 , 4}$ \\
\hline Unemployed registered & Desempleados registrados & 107.677 & 10.840 & 1.013 & 178 \\
\hline
\end{tabular}

Fig. 5. Main socio-economic facts. Source: Ajuntament de Barcelona.

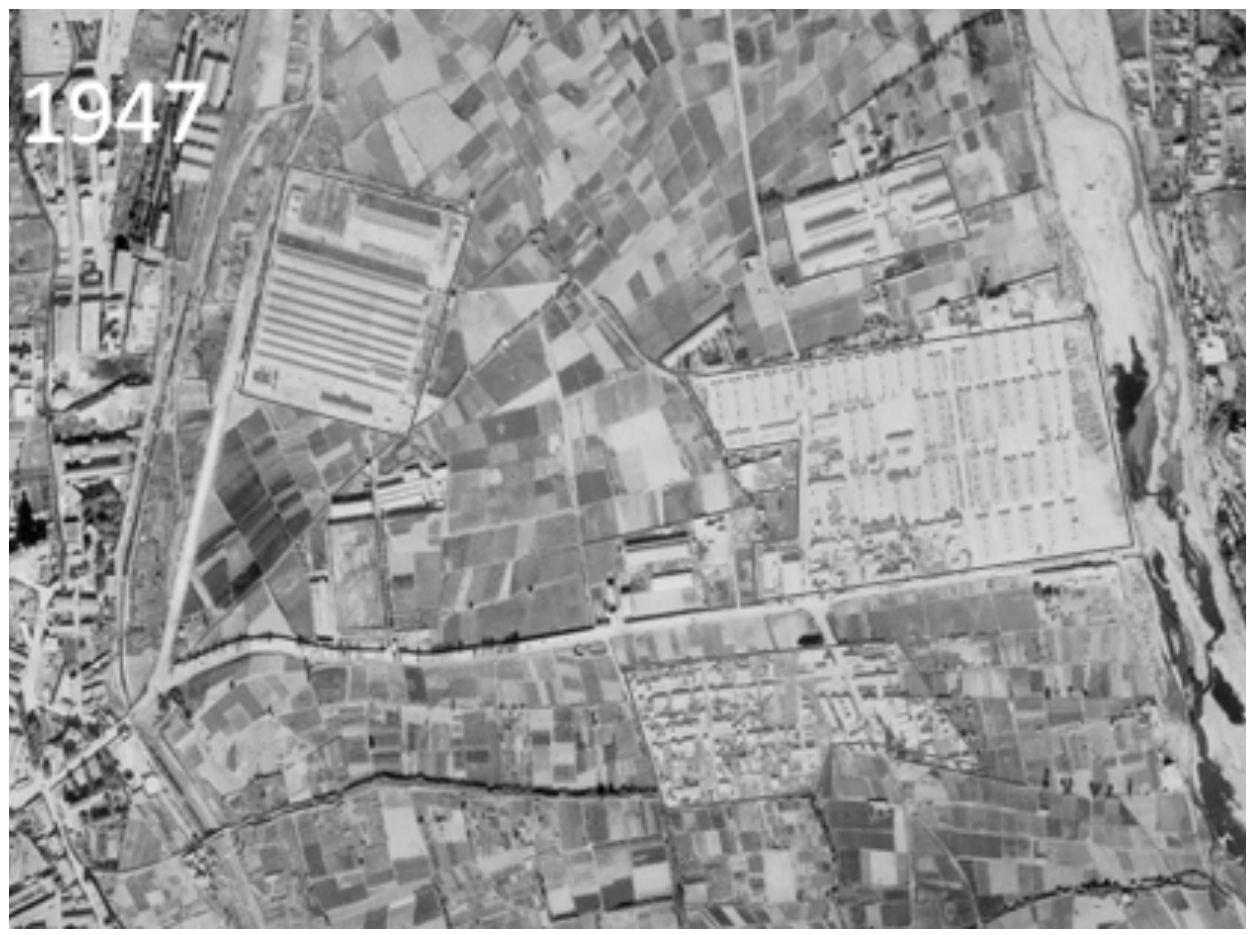

Fig. 6. The Bon Pastor Area, 1947. Source: Institut Cartogràfic de Catalunya. 


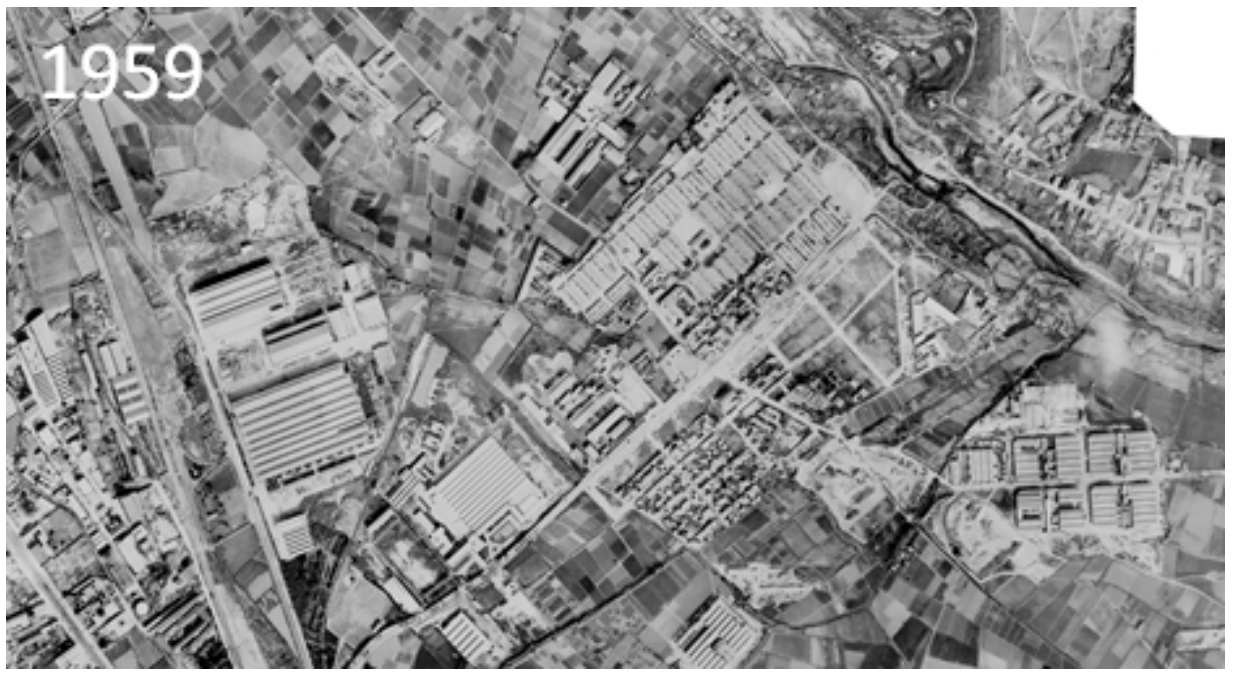

Fig. 7. The Bon Pastor Area in late 1950s showing the growing of industrial and residential areas, 1959. Source: Institut Cartogràfic de Catalunya.

The annexation to Barcelona is the first step in a major transformation of this territory, which will have its climax in 1953 with the Regional Plan of Barcelona. The right bank of the river Besòs will become one of the big new industrial zones and working residence foreseen in this planning.

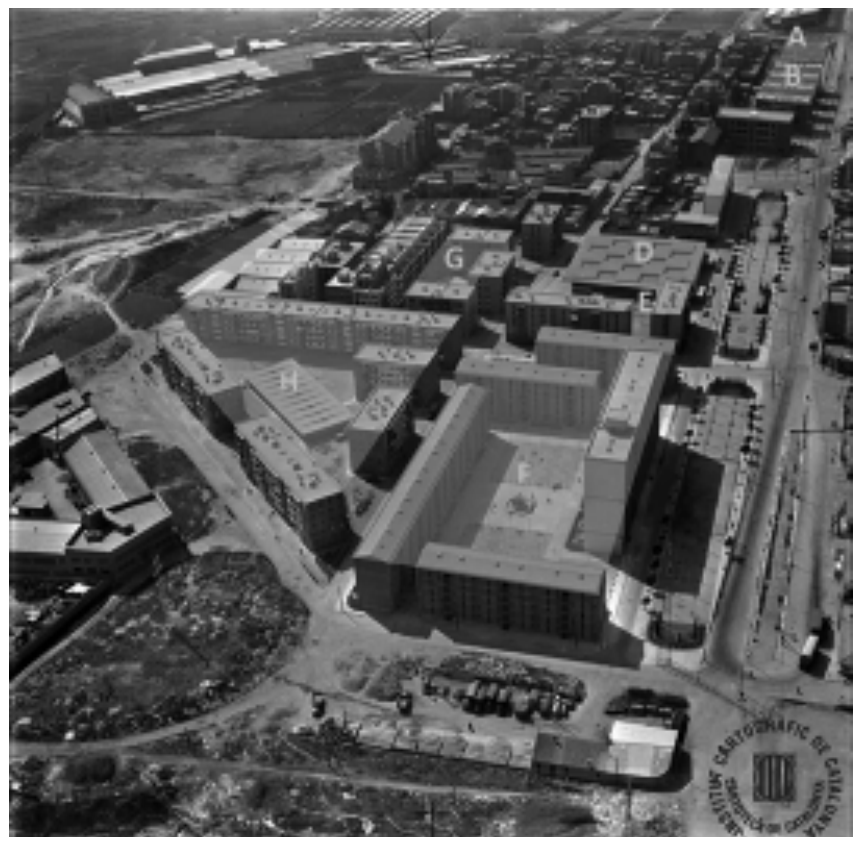

Fig 8. End of 1960. The new residential states in the Bon Pastor Area. Source: Institut Cartogràfic de Catalunya. 


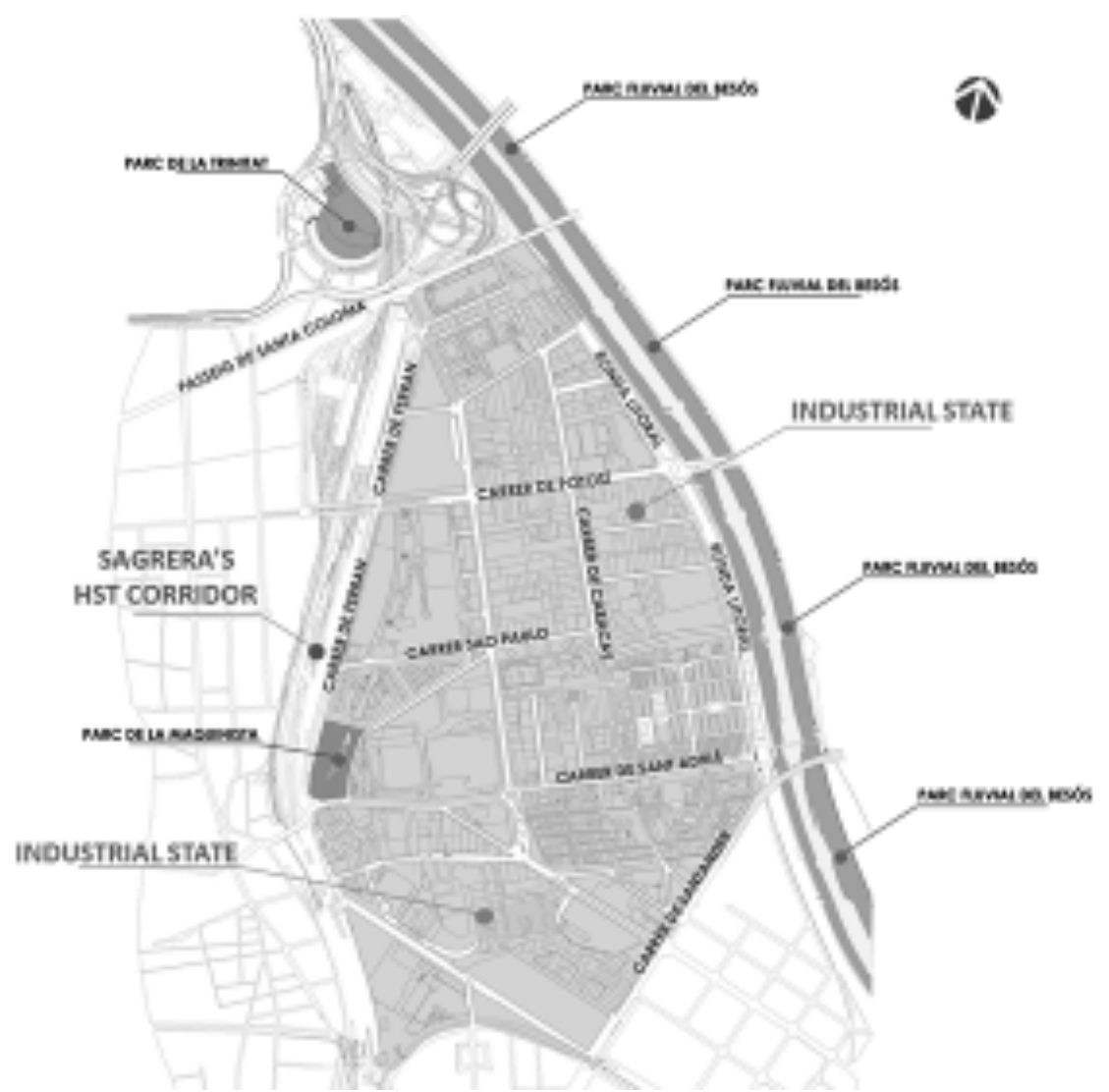

Fig. 9. The Bon Pastor and Baró de Viver Area at the present moment. Source: Institut Cartogràfic de Catalunya.

\section{THE URBAN COHESION PROJECT AND THE WALL OF REMEMBRANCE}

Our role, as Polis Research Centre, when we collaborate with neighbours and/or City Council districts, is the development of preparatory studies on public space and urban design in order to have a "pool" of ideas that can form the basis for the development of actions raised by the residents and the district. In this context, we assign these projects as a teaching element in the M.A. in Urban Design. We call this activity, the "Urban Cohesion" project, intending to explore the possibilities for improving: (1) connection between two neighbourhoods separated by an industrial estate; (2) continuity of project for the Boulevard of Asuncion City; (3) The Besòs river promenade; (4) the Bon Pastor connection with the district of Sant Martí; (5) Bon Pastor's "Remembrance Wall" following the experience developed in Baró de Viver. 


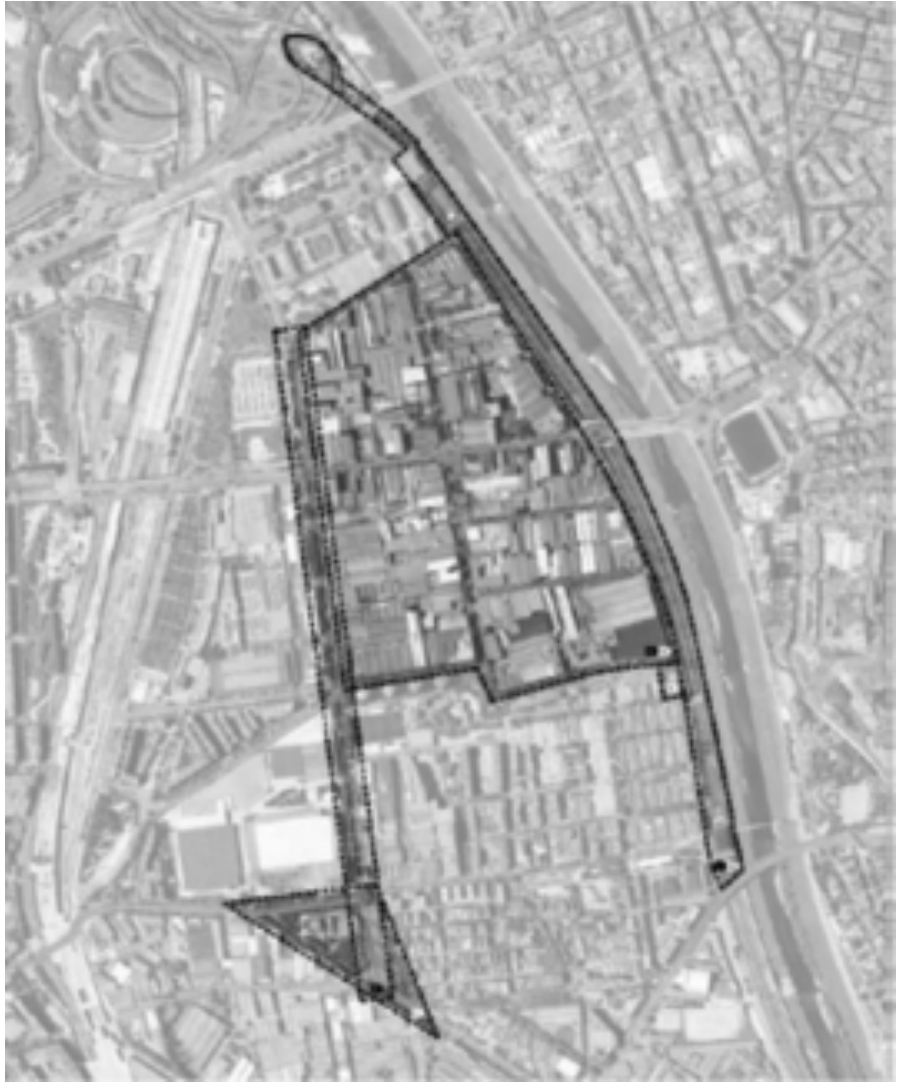

Fig. 10. The plan shows the different areas we are studiyng in the M.A. in Urban Design, Universitat de Barcelona. Source: Antoni Remesar, Bibiana Crespo-Martin.

That is the end of the world, were the words of J. M. Huertas, the first time he was in Baró de Viver. ${ }^{20}$ A lousy transport system. Spatial segregation of neighbourhoods. Invisibility, ignorance, prejudice. Social segregation of the neighbourhoods. Separation and distance between the two neighbourhoods. Unsuccessful urban cohesion. Repression and oppression under Franco's regime. The Church called "missions" to its apostolic activity. Social assistance and almsgiving make up for much of the services to which citizens are entitled.

Maisonettes. Family houses. In a row, next to each other. Some with a small front garden. Small, cold in winter, hot in summer. Humidity. Living in the street, playing in the street. Excellent neighbourly relations. Open doors. Feast. Privations and difficulties have been replaced with some happy memories. Memories and homesickness of living in a village.

\footnotetext{
${ }^{20}$ Josep Maria Huertas, "El fin del Mundo," in Baró de Viver: La Transformación de un barrio (1994-1999), ed. Genaro Villagrasa (Barcelona: CR POLIS. Universitat de Barcelona, 1999), 3.
} 
Sport unites. Sport enhances social cohesion (football, cycling, wrestling). In the neighbourhoods of the Besòs' river bank, have been several wrestling champions. The neighbourhoods, in fits and starts, generate culture. People join in associations of all kinds.

Work is nearby, in the factories of the large industrial estates around the neighbourhoods. Grassroots movements are organized. They claim what they are entitled: transport, health, education, improving the conditions of the built environment. While there is struggle, life goes on. Or, while there is life, the struggle continues.

Employment policies and social services are insufficient to promote urban cohesion of a territory. The simple design of parts of the territory are insufficient to realize its urban cohesion.

Because of the work developed in the Master in Urban Design, we tend to prioritize "city making," the design and construction of public space that will enable territorial integration; a public space that will become the guarantor of visibility, accessibility and connectivity between both neighbourhoods, Baró de Viver and Bon Pastor, and between them and the rest of the city. Searching for an inclusive public space for residential and productive purposes. The projects propose a base of ideas for cooperative and participatory work between neighbours and local administration in order to get urban cohesion within the framework of urban regeneration processes in this territory. ${ }^{21}$

The development of participatory processes in Baró de Viver that we started in 2005 has had its reward. This small neighbourhood and the struggle of its neighbours have achieved most of the objectives from the participatory workshops: Day Centre building, civic square urban gardens, Rambla Ciutat d'Asunción, Monument to the small houses. ${ }^{22}$ Let's focus on the mural of Remembrance which is the key factor to explain the White Centre remembrance rescue.

\footnotetext{
${ }^{21}$ Antoni Remesar, Xavier Salas, Tomeu Vidal, Bibiana Crespo and Roser Masip, Cohesión urbana. Construyendo la memoria (Baró de Viver - Bon Pastor. Dos exposiciones) (Barcelona: CR POLIS. Universitat de Barcelona, 2016).

${ }^{22}$ We will not go into details since they can be followed in our production. See: Samuel Padilla, Producción de Espacio Público (X) Participación Ciudadana. El proyecto de espacio público resultado de procesos de participación ciudadana (Barcelona: CR POLIS. Universitat de Barcelona, 2015. http://tdx.cat/handle/10803/309288); Antoni Remesar, Xavier Salas, Samuel Padilla and Dánae Esparza, "Inclusion and empowerment"; Antoni Remesar, Xavier Salas and Tomeu Vidal, "Urban Governance and Creative Participation in Public Space and Public Art," in The Art of Urban Design in Urban Regeneration, ed. Antoni Remesar (Barcelona: Edicions de la Universitat de Barcelona, 2016); Xavier Salas, L'artista com a facilitador en els processos de participació ciutadana: el cas Baró de Viver a Barcelona (Barcelona: Universitat de Barcelona, 2015).
} 

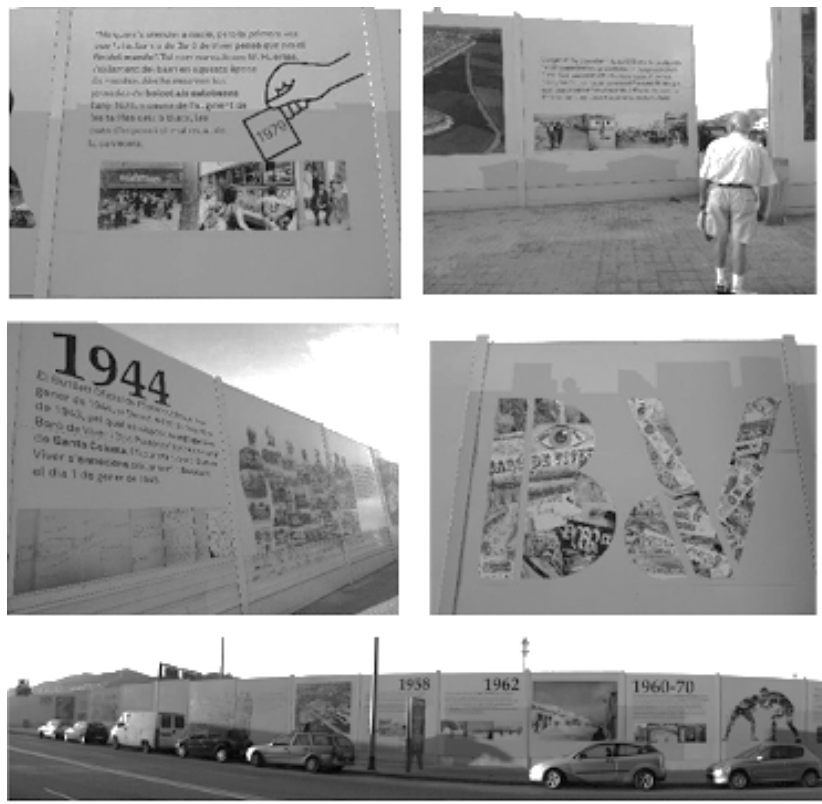

Fig. 11. Images of the Mural of Remembrance in Baró de Viver. Source: Antoni Remesar, Bibiana Crespo-Martin.

In late 2008, as a result of collecting complaints from neighbours because of the noise caused by La Trinitat road junction, the City of Barcelona started the project of a sonic wall. Its installation was as an excuse to develop a participatory process with the neighbours. Sonic screens become the support for the Mural of Remembrance, designed with the contributions of images and memories of neighbours. The mural was unveiled in February 2011 and other districts raised to the Town Council the chance to develop similar projects. The municipal elections in June of that year, truncated these projects, when the Mayor of Barcelona was taken over by the nationalist right.

The Neighbours Association in Bon Pastor was interested to develop a similar project and contacted with our research centre. So, in 2013 we started a participatory project to provide a similar symbolic device to the Bon Pastor. Since the beginning of the work, Bon Pastor's residents expressed the conviction that "their mural" has not to be a "mural."

The linear medium in Baró de Viver, oriented the organization of the timeline developed by neighbours. By acting on a surface, it was almost automatic to articulate the "atlas" of more than 4,000 pictures and documents provided in participatory panels. The work was laborious but relatively easy as the neighbours were selecting images, the more representative documents, the more iconic ones according to their criteria. We had a wall, we create a mural: The Wall of Remembrance. 
The situation is more complex in Bon Pastor. All along, neighbours have agreed that their action on remembrance must "happen" in different areas of the neighbourhood. They also want to articulate a more in-depth content departing from three thematic axis: (1) urbanization, (2) industry - remembering their industrial past, present and future, (3) grassroots movements.

Right now, we do not have a linear support (wall) so the project will not be a wall of remembrance but, surely, a spatial system for remembrance: (1) in some points, nodes, of special significance for the residents; (2) unfolded on the vertical, horizontal and air planes of public space; (3) showing "referential and iconic elements" through various techniques that can range from photography to object.

The process is underway. It is a process that belongs to the neighbours and, our team, on ethical grounds implicit in a process of civic participation, cannot and do not want to advance conclusions. ${ }^{23}$ Thereafter, neighbour's decisions will be the ones the own neighbours should negotiate with the political and technical bodies of Sant Andreu's district, to really show that if they want, neighbours can become agents and not just actors in the decision-making processes on "citymaking."

In any case, in the context of the "urban cohesion" project, we explored the possibilities for this "remembrance spatial system." And with this purpose, we focused in one specific element, really important for the remembrance of the neighbourhood: The White Centre. The White Centre was a building that has been the site of many of the resistance movements to Franco in Bon Pastor.

In the industrial colony built circa 1930, Enrique Sanchis, the owner of the industry, built a chapel, designed by the Santa Coloma's municipal architect Josep Alemany i Juvé. Between 1936-1939 this building became a Popular Athenaeum. Following entry of Franco's troops in Barcelona, the building was converted into a health and care center, known by residents as "the Dispensary." The center was managed by pious associations of the Catholic Church.

Early 1940, the Church began the construction of the parish church, with buildings for the "Workers' Home," a charitable dispensary and a school which was fully completed in the early 1960s. It was at this time, within the framework of the "Associations Act" (1964) that the old chapel became the headquarters of the Householders Association, direct antecedent of the Neighbours Association of Bon Pastor. ${ }^{24}$

In this context, the building was used, as the headquarters of the clandestine Partido del Trabajo de España (PTE), of some excursionist Groups and Cultural

\footnotetext{
${ }^{23}$ You can follow all the news about the advances of the project in https://femlamemoriadel bonpastor.wordpress.com/proceso-participativo/.

${ }^{24}$ Martín Checa-Artasu and Carme Trave, Bon pastor, La història d'un barri (Barcelona: Ajuntament de Barcelona, 2007).
} 
Association: chess, a film club and the Association of Housewives. Thus the White Centre, became a true civic centre and antagonistic to the cultural and associative activities sponsored by the Church.
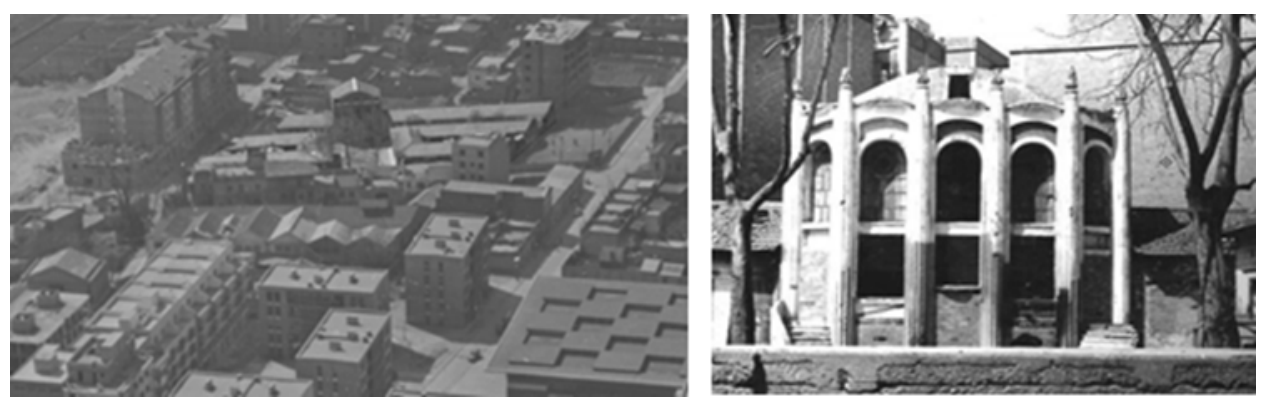

Fig. 12, 13. Above left and right, The White Centre as it was in 1970 (Sources: left, Martín ChecaArtasu and Carme Trave, Bon pastor; right, Sergio Fuentes Milà, L'esglèsia del Bon Pastor de Barcelona. Història, art $i$ arquitectura. Source: Ajuntament de Barcelona, 2015.

Fig. 14. Right, A model of the White Centre built by one neighbour and shown in a public forum in the context of the participatory process. Source: Antoni Remesar, Bibiana Crespo-Martin.

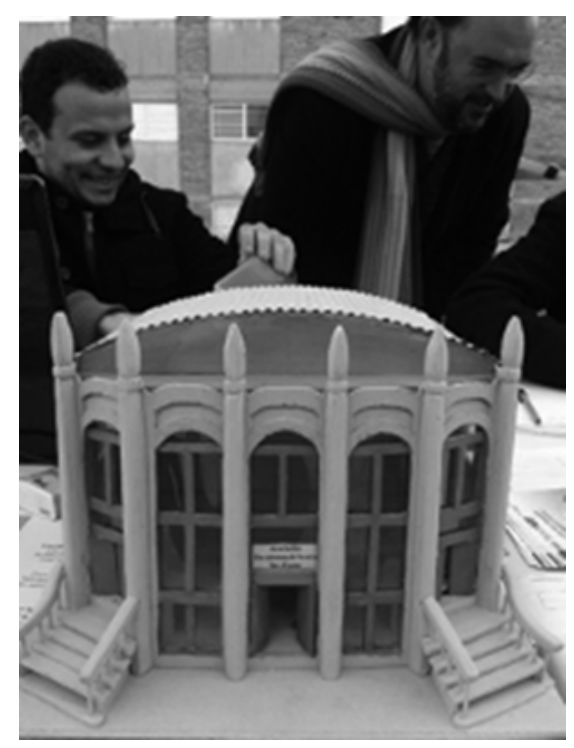

The White Centre, was the site of countless trade union and workers' meetings, in their fight against Franco. In 1976 the Neighbourhood Association was evicted from the building that later was demolished. The City Council bought the premises in 9 MPTA (the nominal value in 2001 Euros would be around $55,423 €$ ), years later, on the site of the White Centre it was built the current Bon Pastor's Civic Centre.

The White Centre is an identitarian symbol of a fighter, democratic and organized neighbourhood. Therefore, its remembrance must be rescued. Especially in the time when the neighbourhood is developing the project "Remembrance of Bon Pastor." 


\section{WALLS AND PARTY WALLS IN BARCELONA}

An important part of the territory of Barcelona has a specific morphology: contiguous plots with juxtaposed constructions. Local regulations governing the height, depth and alignment of the buildings, and vary over time producing the appearance of walls and party-walls. In some cases, the appearance of these walls is due to abrupt changes of gradients.
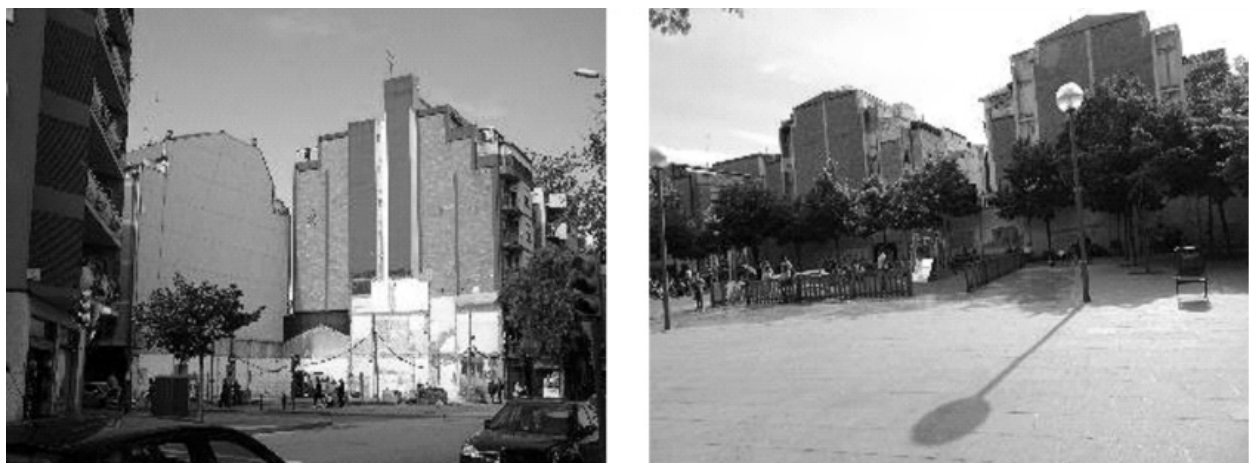

Fig. 15-17. Examples of party-walls in the neighbourhood of Bon Pastor. Like in other parts of the city party-walls are an urban landscape problem. Source: Antoni Remesar, Bibiana Crespo-Martin.

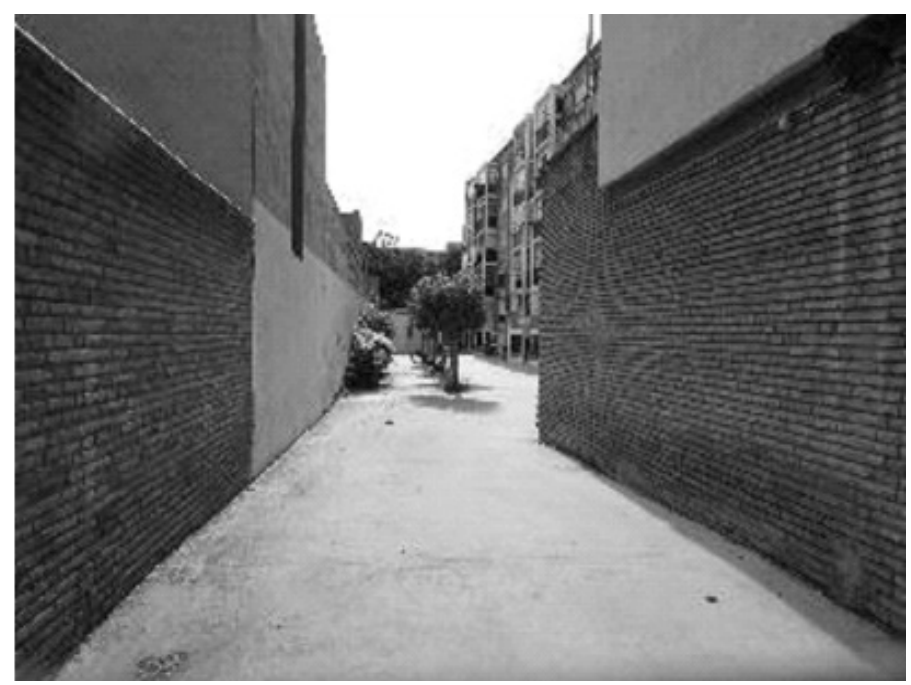

Although Barcelona is not known for being a city of murals since 1979 it has been developed a certain policy to improve the appearance of these walls and dividing walls. Schematically interventions on these walls are divided into several groups: (1) art interventions (esp. graffiti interventions), (2) structural actions, (3) sustainable murals, (4) integration of walls in public space projects, (5) districts interventions, (6) walls of collective appropriation. 
1. Art interventions often using "trompe l'oeil" and, more recently, graffiti interventions:
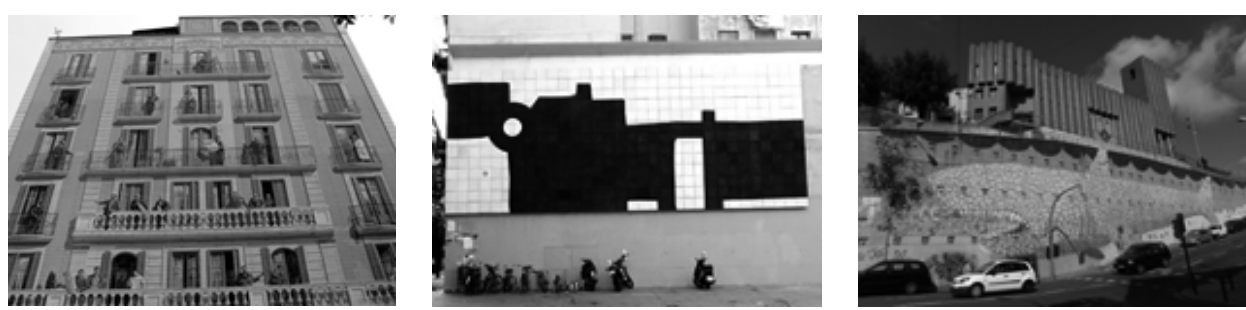

Fig. 18-20. Balcones de Barcelona by Cité Creation; Chillida's mural near the MACBA; mural made by Blu in the Carmel neighbourhood. Source: Antoni Remesar, Bibiana Crespo-Martin.
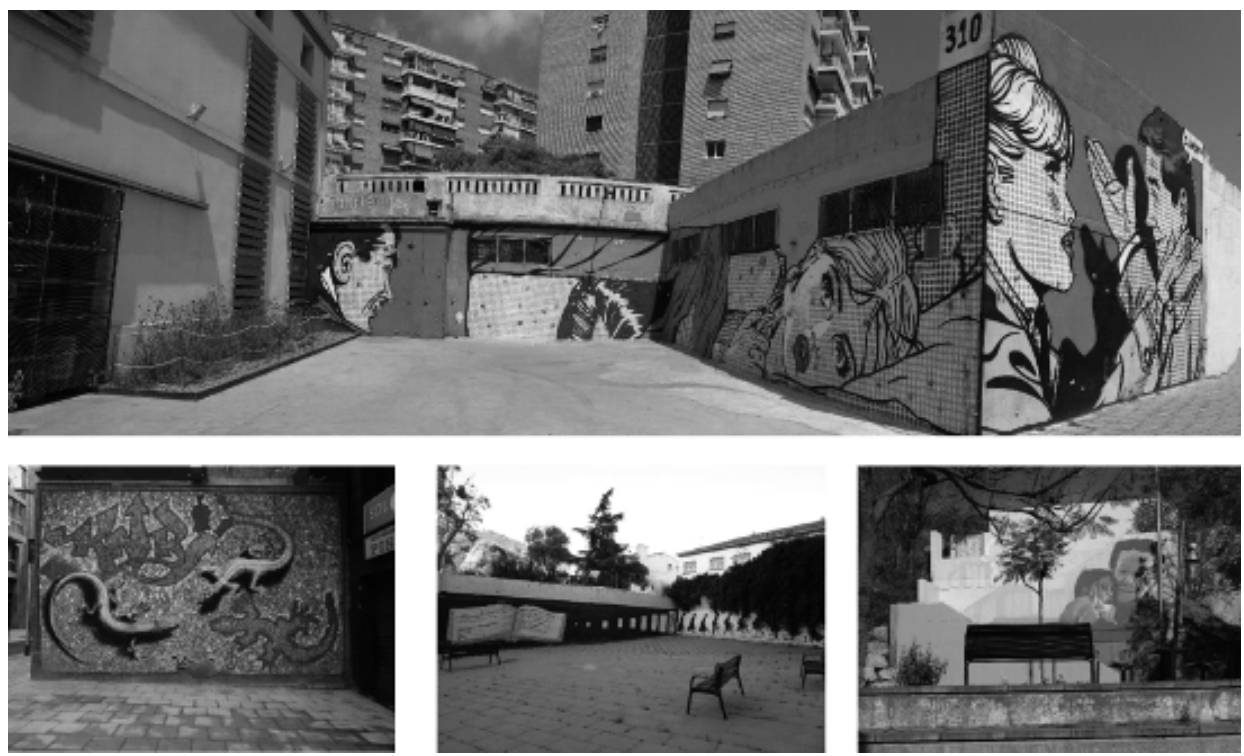

Fig. 21-24. Several graffiti murals in the neighbourhoods of Guineueta, Les Corts, Sant Genis and Trinitat Nova. Source: Antoni Remesar, Bibiana Crespo-Martin.

2. Structural Actions with the objective of improving isolation conditions of the buildings:
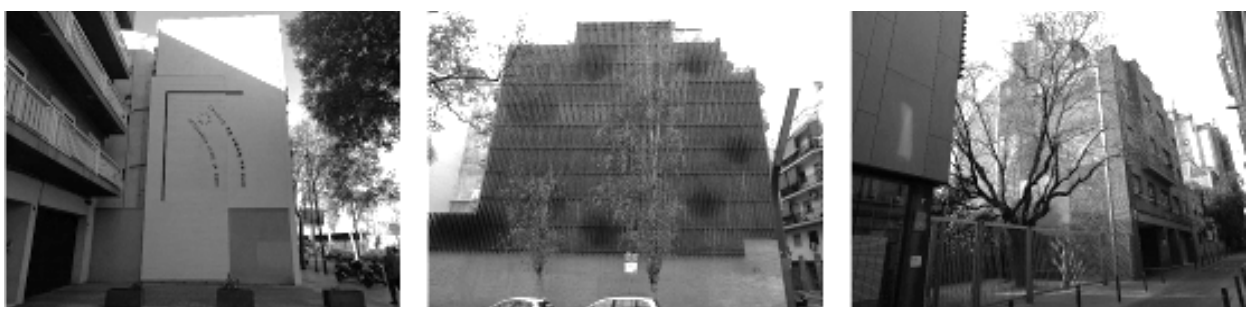

Fig. 25-27. Three examples of structural solutions within the framework of the campaign to improve the urban landscape of Barcelona City Council. Source: Antoni Remesar, Bibiana Crespo-Martin. 
3. Sustainable murals. As an evolution of the previous concept they are made to integrate eco-systems or to reduce energy consumption:
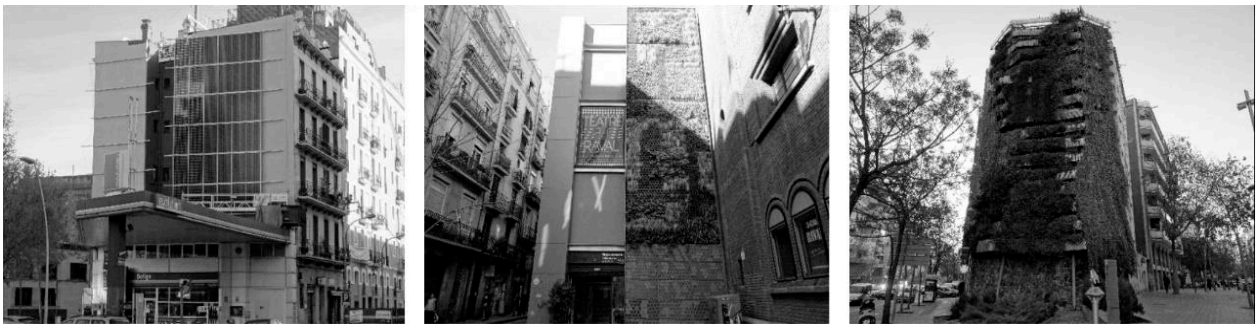

Fig. 28-30. An example of party-wall with solar panels and two other with vertical gardens. Source: Antoni Remesar, Bibiana Crespo-Martin.

\section{Integration of walls in public space projects:}

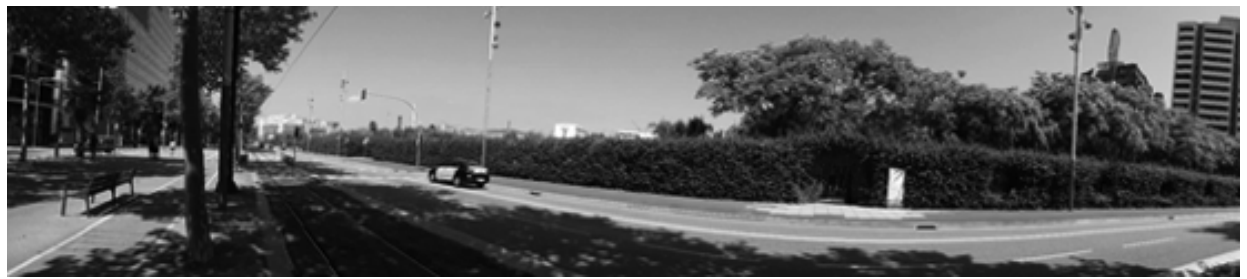

Fig. 31. Green wall in the Diagonal's Central Park, work by Jean Nouvel. Source: Antoni Remesar, Bibiana Crespo-Martin.
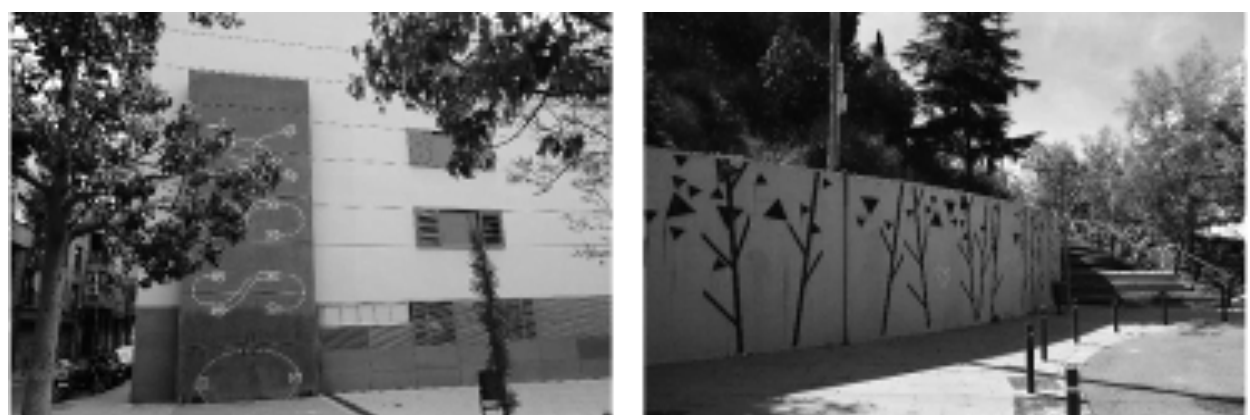

Fig. 32-34. Three examples of integration projects in public space: neighbourhoods of Prosperitat, Polvorí and Congrés. Source: Antoni Remesar, Bibiana Crespo-Martin.

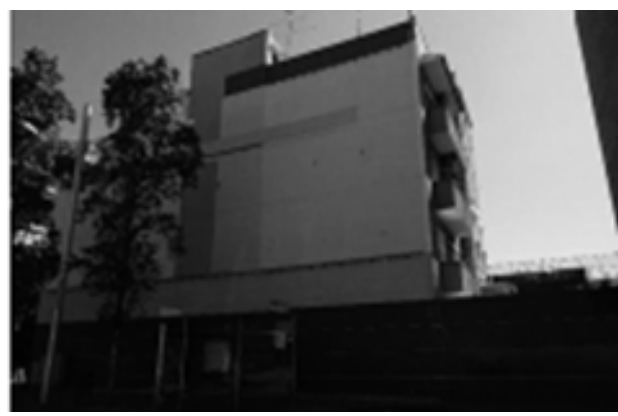


5. Districts interventions with the objective of answering the demands from neighbours and/or artists. The good example are The Literacy Murals in Les Corts. ${ }^{25}$ Since 2013, the Les Corts district has developed the policy to use some enclosing walls between buildings or building fences as a temporary support for the realization of murals. Its subject is Catalan literature. Every year they choose several writers on which the mural shall deal. In the first two editions, the idea of using a wall expectant either for demolition or for new building actions, was met while guaranteeing temporary murals. The expressive language used was graffiti.
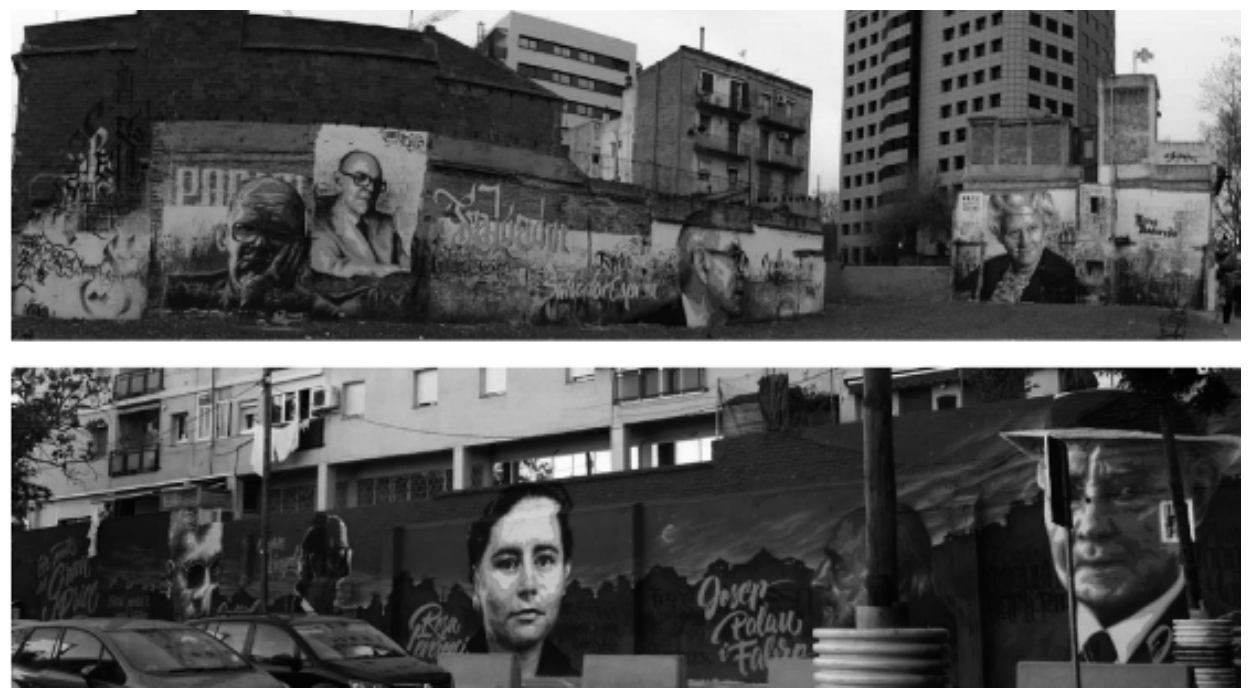

Fig. 35, 36. Literacy walls in Les Corts, 2013 and 2014. Source: Antoni Remesar, Bibiana Crespo-Martin.

${ }^{25}$ POLIS Research Centre was commissioned to carry out the actions of Literary Mural planned for 2015. The proposed wall is located at Avenida de Chile; it should be permanent and is the closing wall that delimits the Polo Club with the Avenue. Unlike previous proposals, this wall is enormous, approximately 400 meters long by an average of 4 meters high. A first analysis of the wall, its location and context, clearly show that no intervention should be based on the language of street art, and required a project aiming to permanence, and that could become a work of public art. We assess, too, that an Urban Design international and interdisciplinary team, was the best solution and could raise an artistic solution complementing the urban design of the area. BUT... The Association of Residents of the area when knowing the idea of the District reported a total rejection of this intervention, especially if carried out in the style of those made in previous years. So, the project was paralyzed, because the neighbours protests coincided with the City Council polling process. See AA.VV., "Cohesión urbana. Mejorando la conectividad entre Baró de Viver y Bon Pastor" On the W@terfront 38 (2) (2015). 
6. Walls of Collective appropriation. Developed by citizen groups and generally assertive social or urban deprivation in the area. Some of them linked to the squatter movement.
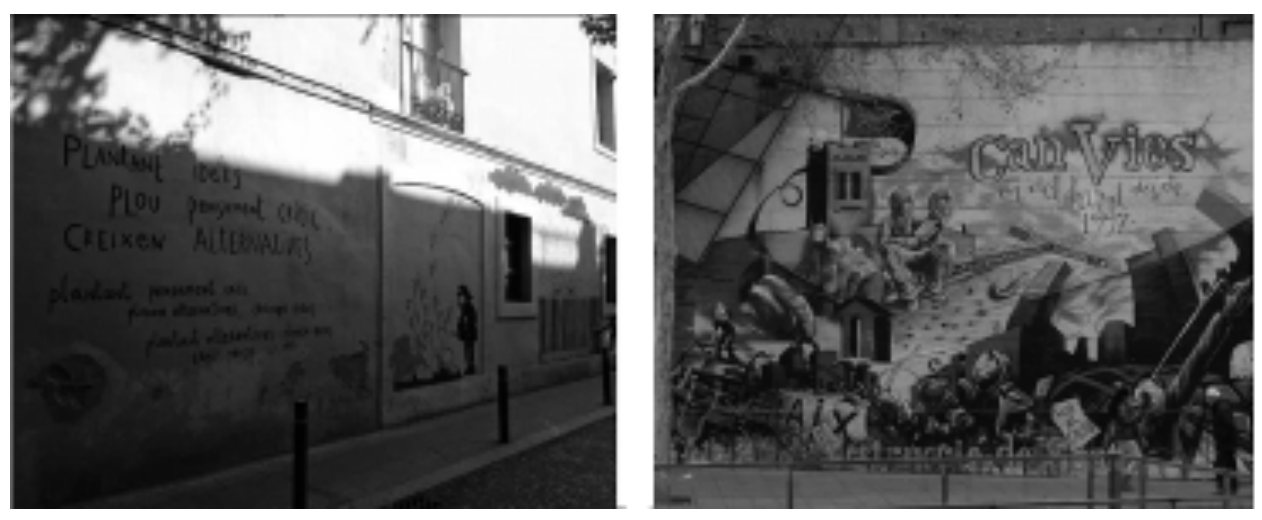

Fig. 37-39. Three examples of murals made by citizen groups in the neighbourhoods of Gracia, Sants and Can Peguera. Source: Antoni Remesar, Bibiana Crespo-Martin.

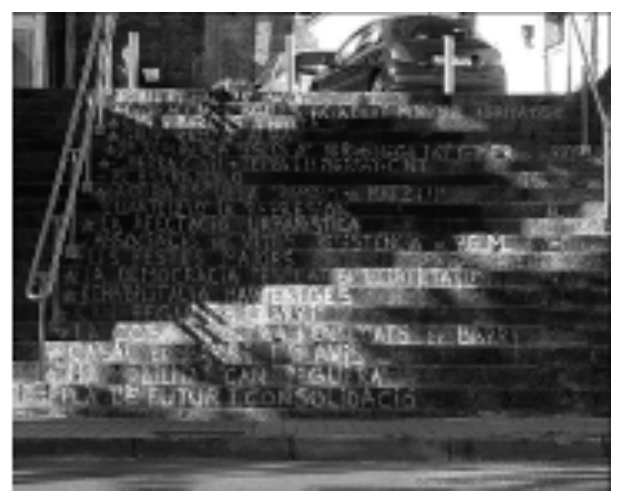

Walls and party-walls are an important part of the Barcelona's landscape and of the neighbourhood of Bon Pastor too. So, its integration into the remembrance project will be relevant.

\section{HOW WE ADVANCE IN THE IDEA TO "RESCUE THE MEMORY" OF THE WHITE CENTRE}

As mentioned above, in the early 1980s, the City Council bought the site where the White Centre was located. On this site was built in the 1980s the current Civic Centre and part of the space was designed as a square, the square Robert Gerarhd. The site has several possibilities for action but also raises corrections on the design of public space. 
During the academic year 2015-2016, one of the project teams of the Master in Urban Design ${ }^{26}$ tackled the problem of starting to work on the spatial memory system of the Bon Pastor, dealing with the subject of rescuing the remembrance of the White Centre. The project aimed to order the square in relation to the potential development of an iconic element referred to the White Centre and to articulate the relationship between this point and other points of the territory that might be part of the spatial remembrance system. To do this, it was essential to think about the development of a system of "urban software,"27 surely supported on a signalling communication system.
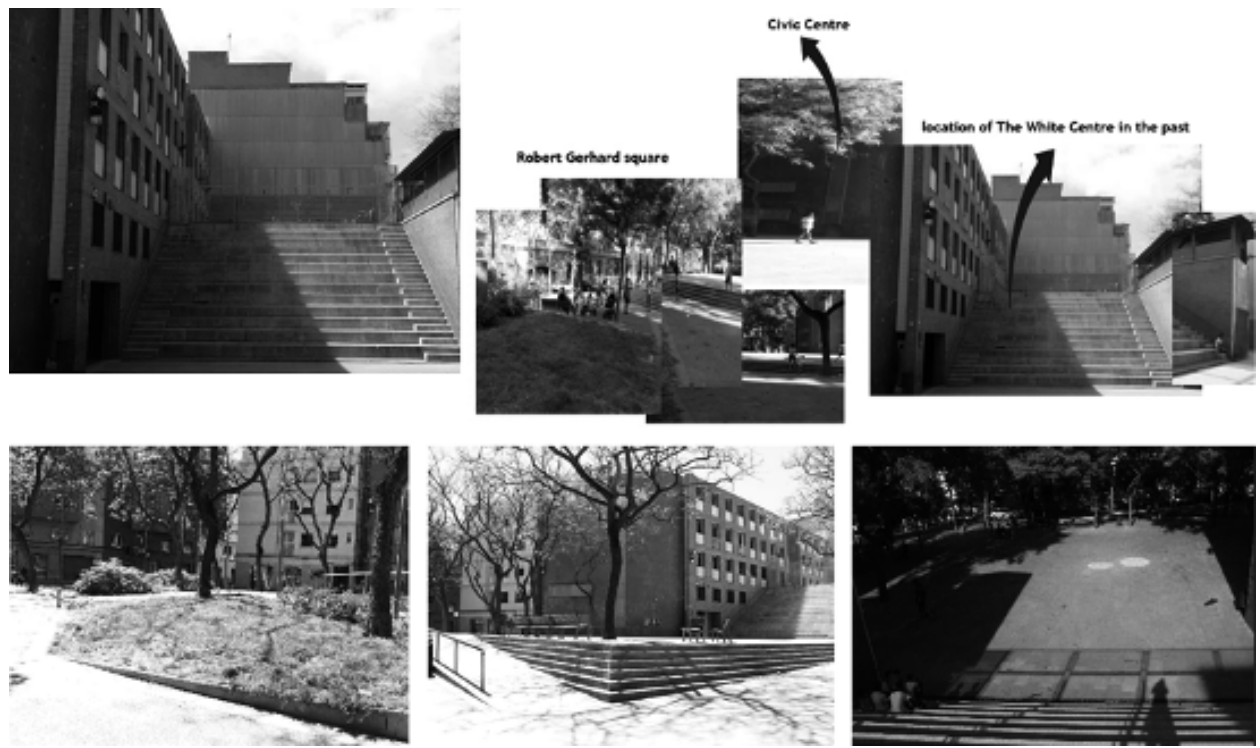

Fig. 40-44. Grades of the Civic Centre underused and finishing in a party-wall. The design of hard parts and green parts of the square allow reordering it, to value the site of the possible intervention on the remembrance of White Centre. Source: Antoni Remesar, Bibiana Crespo-Martin.

\section{From "painted trompe l'oeil" to an sculptural mural}

The initial idea, discussed even with some neighbours, was to use the stands as a support of a painting in "trompe l'oeil" consisting of a giant reproduction of the shape of the old White Centre. This intervention did not solve the visible

\footnotetext{
${ }^{26}$ This was an International and interdisciplinary team with the participation of Carlos Herrera (Colombia), Monica Bellido (Mexico), Javier Vergel (Spain), Xie Danlan (Xina), Negumi Kamei (Japan).

${ }^{27}$ Pedro Brandão, La imagen.
} 
edges of the party-wall. Therefore, in a second stage, we thought on a painting on the party-wall. This idea meant introducing a new design in the stands to give continuity to the public space of the square, to improve the current characteristics of the terraces.
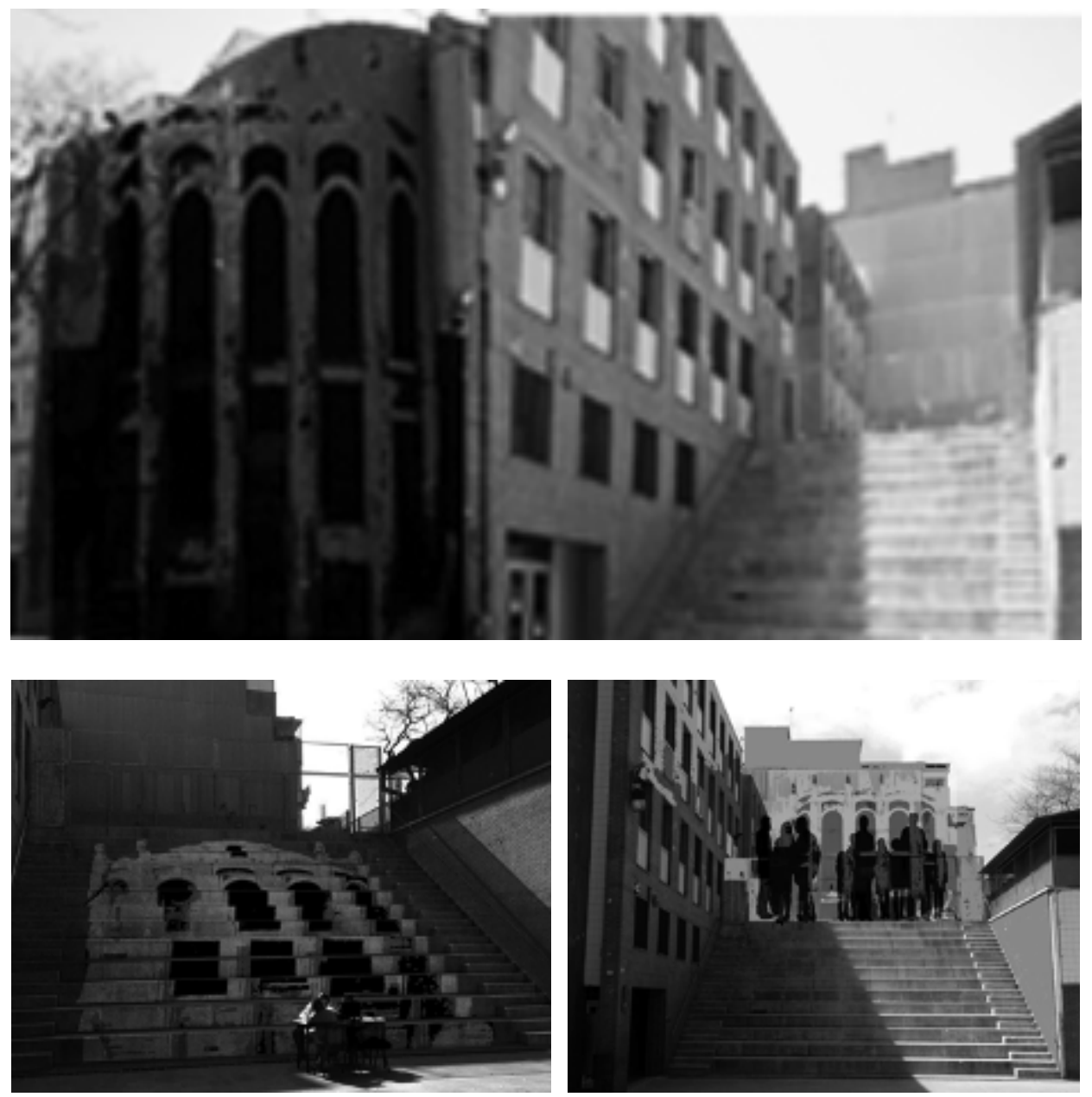

Fig. 45-47. One of the projects in trompe l'oeil on the building of the Civic Center; proposed projects in "trompe l'oeil" on the steps of the Civic Center; a pictorial project on the great party-wall of the Civic Center. Source: Antoni Remesar, Bibiana Crespo-Martin.

Gradually, the idea evolved about the redesign of the square and the initial studies on the "software" for the communication system that will relate this point in the space system with other possible points and that, at that time, were under discussion and study by the neighbours in the framework of the participatory process on the remembrance system for the Bon Pastor. 
From the projection onto the floor, to

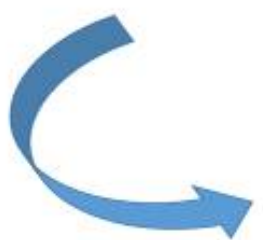

the projection onto the party wall
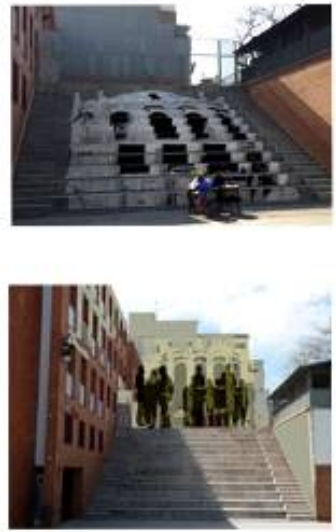

From the two-dimensional image, Trompe-I'oeil

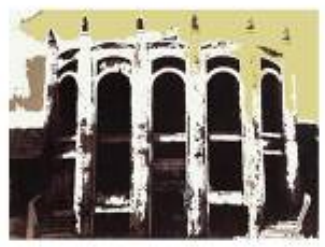

To a three-dimensional graphic representation
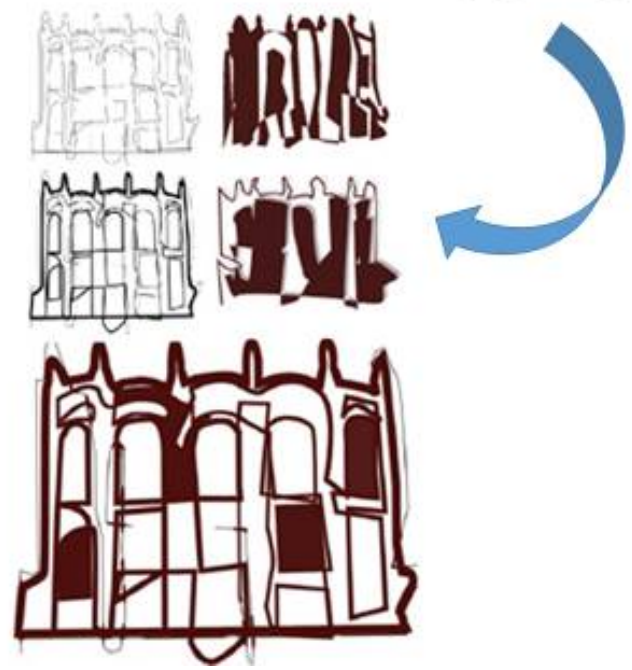

Fig. 48. The conceptual and critical development of the initial ideas led the team to rethink the realistic representation of the White Centre and to develop a solution that would also allow solving structural aspects of the median wall. Elaborating the image of the White Centre through a process of solarisation, led to an abstraction of the image that could also be treated materially with cor-ten steel cuts on the wall. Source: Antoni Remesar, Bibiana Crespo-Martin. 


\section{The beginning of a possible "remembrance track"}

The sculptural solution adopted for the representation of the White Centre, allowed the systemic treatment for the remaining possible locations of the memory space system in Bon Pastor. This solution, in addition, allowed starting from graphic documentation, mainly photographic, and through simplification to obtain more schematic and/or abstract images.

The sculptural work needs of a support for its implantation. A large plane on which to anchor the sculpture. This support, in addition, can play a relevant role in the structural treatment of the party-wall. It also facilitates the inclusion of a bench overlooking the terraces and open views towards the square, facilitating in this way the inclusion of the sculpture in the reorganization of the public space of the square.
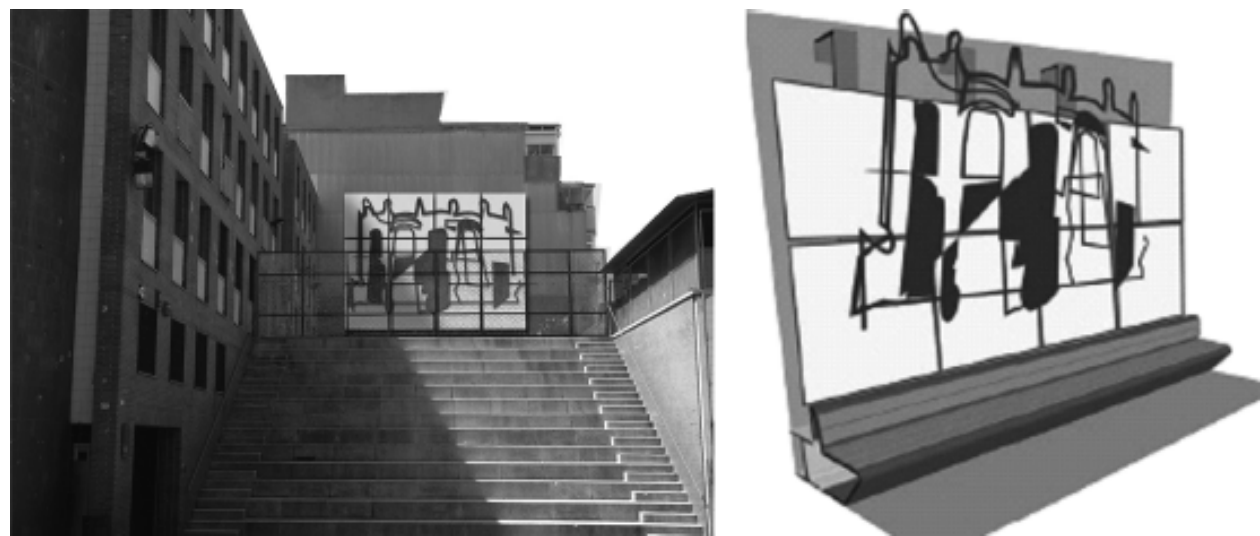

Fig. 49-50. Two renders of the proposal for the White Centre remembrance element. Source: Antoni Remesar, Bibiana Crespo-Martin.

This sculptural option, with a thickness of a few millimeters, allowed to study its application in other possible points of the territory: the houses that will remain of the old settlement "Milans del Bosch" (known as the "Cheap Houses") and that will become a centre of Interpretation associated with the Museum of History of the City of Barcelona; the remembrance of the neighbourhood's claim movements, as would be the case of the claim for the Metro station and that could be installed in the atrium of the Bon Pastor station; the remembrance of the old municipal market, now demolished and awaiting its reconstruction in the same place or the memories associated to the old soccer field that according to the District of Sant Andreu will become a space for minority sports. 


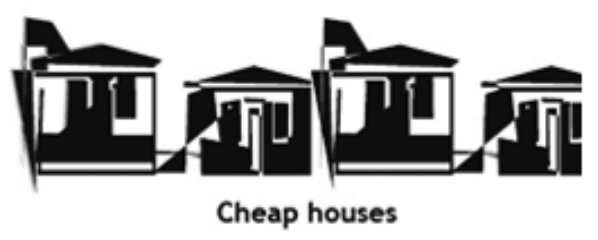

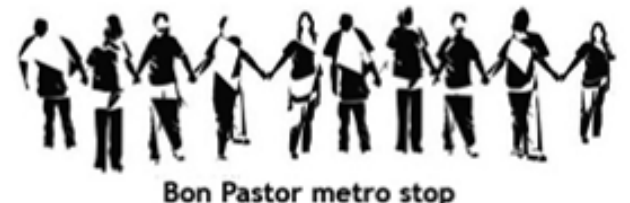

Bon Pastor metro stop

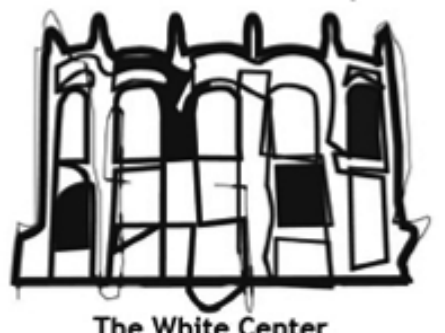

The White Center

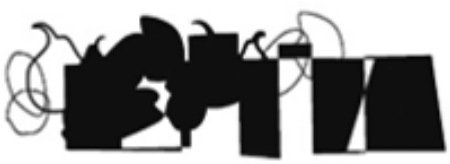

Market

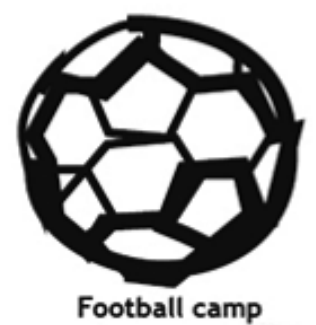

Fig. 51. Exploration of applying the visual results of the White Centre to other remembrance sites in the neighbourhood. Source: Antoni Remesar, Bibiana Crespo-Martin.

\section{Creating the route or "remembrance track": directional signage and marking sites}

Our exploratory work does not always coincide in time with the development of participatory processes. This was the case for spatial remembrance system in Bon Pastor. We knew that the neighbours did not bet on a mural, we knew that they intended to spread the system in the territory. But, in March 2016, the neighbours had not yet agreed about the precise identification of the territory's sites (they would specify it in the workshops developed in November 2016). Therefore, based on the available data, we anticipate a hypothesis of spatial distribution that would allow us to advance the development of all the system elements (see figure 52).

Now the work was oriented in two directions: (1) signalling and identifying the specific site and (2) signalling the path or route linking the different sites. 

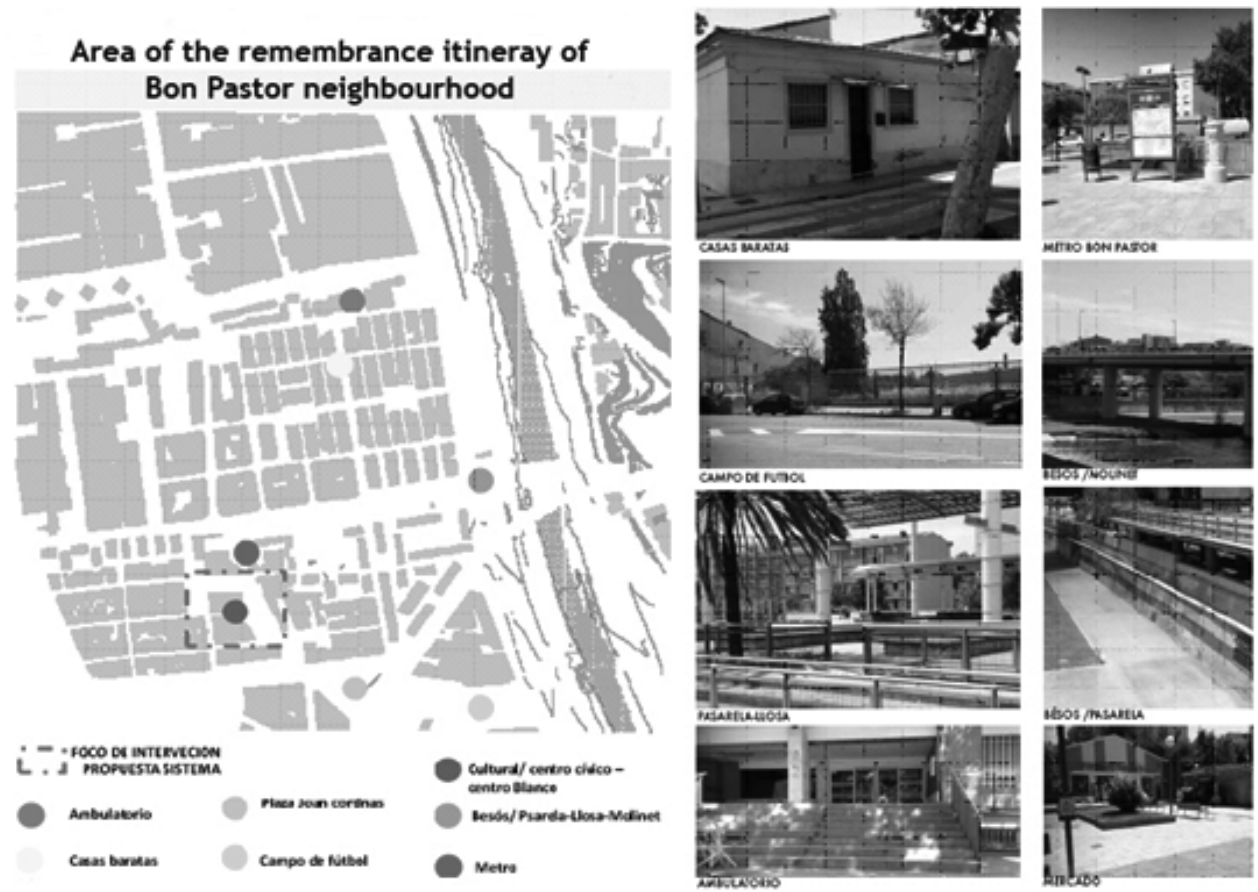

Fig. 52. Our model identified, besides the site of the White Centre, the possible locations to be rescued in the remembrance system: the outpatient clinic, the Joan Cortinas square, the old soccer field, the Molinet Bridge on the Besòs river, and, of course, the site where an island of the old "cheap houses" will be kept. Source: Antoni Remesar, Bibiana Crespo-Martin.

We solve aspect 1 by using the "panot" ${ }^{\text {"28 }}$ as the support of information on the site (see figure 53).

To establish the continuity of the routes, we opted for an adapted version of the directional orientation system, basically pedestrian, which has been found throughout the city since the end of the 2000s. Placed in a specific point of the territory, for example the White Centre, we can follow towards another one, once the signage indicates us one or several possibilities to follow with our remembrance route.

\footnotetext{
${ }^{28}$ The panot is a piece of hydraulic concrete of $20 \times 20 \times 5 \mathrm{~cm}$ that since the decade of 1910 has been used extensively to pave the sidewalks of the city and that constitutes one of the identifying elements of the image of the City in Barcelona. See Dánae Esparza Lozano, El diseño del suelo: el papel del pavimento en la creación de la imagen de la ciudad (Barcelona: TDX. CAT, 2014. http://tdx.cat/handle/10803/146248).
} 

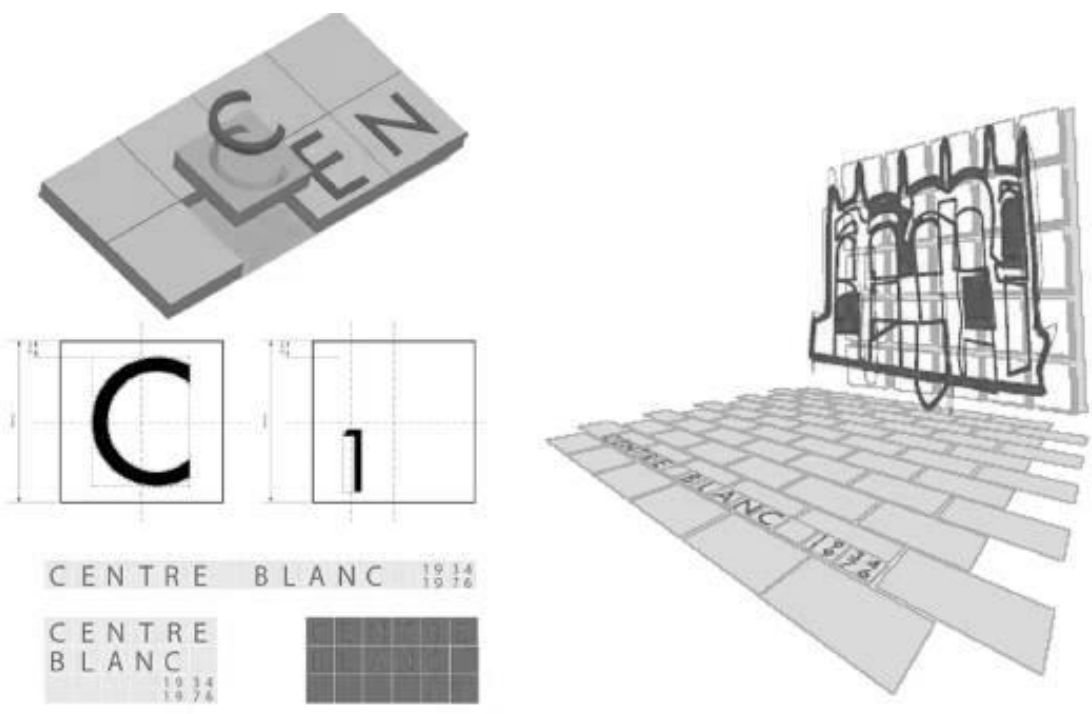

Fig. 53. Render of the use of panots to mark the site. The name of the site is embedded in each of the panot's pieces, by means of letters of cor-ten steel, following the materiality that supports the iconic elements of the system. Source: Antoni Remesar, Bibiana Crespo-Martin.

\section{SIGNAGE APPLIED TO SYSTEM}
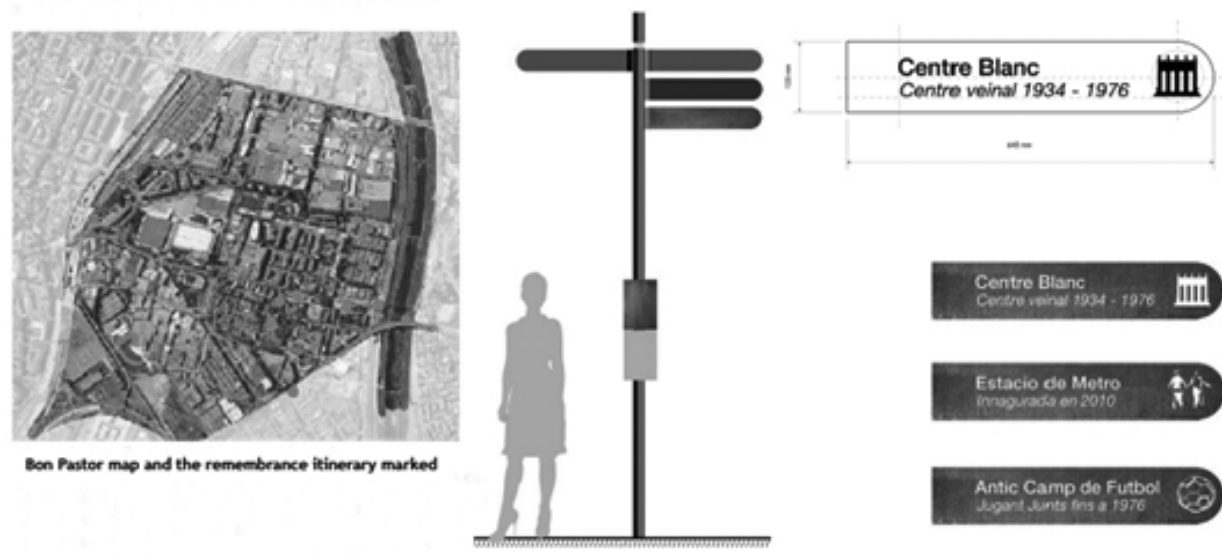

Bon Pastor map and the remembeance itinerary marked

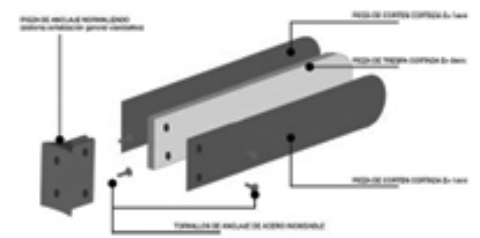

Fig. 54. Scheme of the directional orientation system of the Bon Pastor Remembrance Track. Source: Antoni Remesar, Bibiana Crespo-Martin. 
Finally, the team had to develop the integration of the system into the public space. We will easily understand that integration in the public space cannot be developed in a unitary way, since each intervention will make sense within the framework of existing space design, contrary to the iconic elements that symbolically mark a site, the elements that indicate the name with which we know them and the directional signalling system. Thus, the team focused on improving the public space of the square and on the integration of the symbolic intervention on the White Centre.
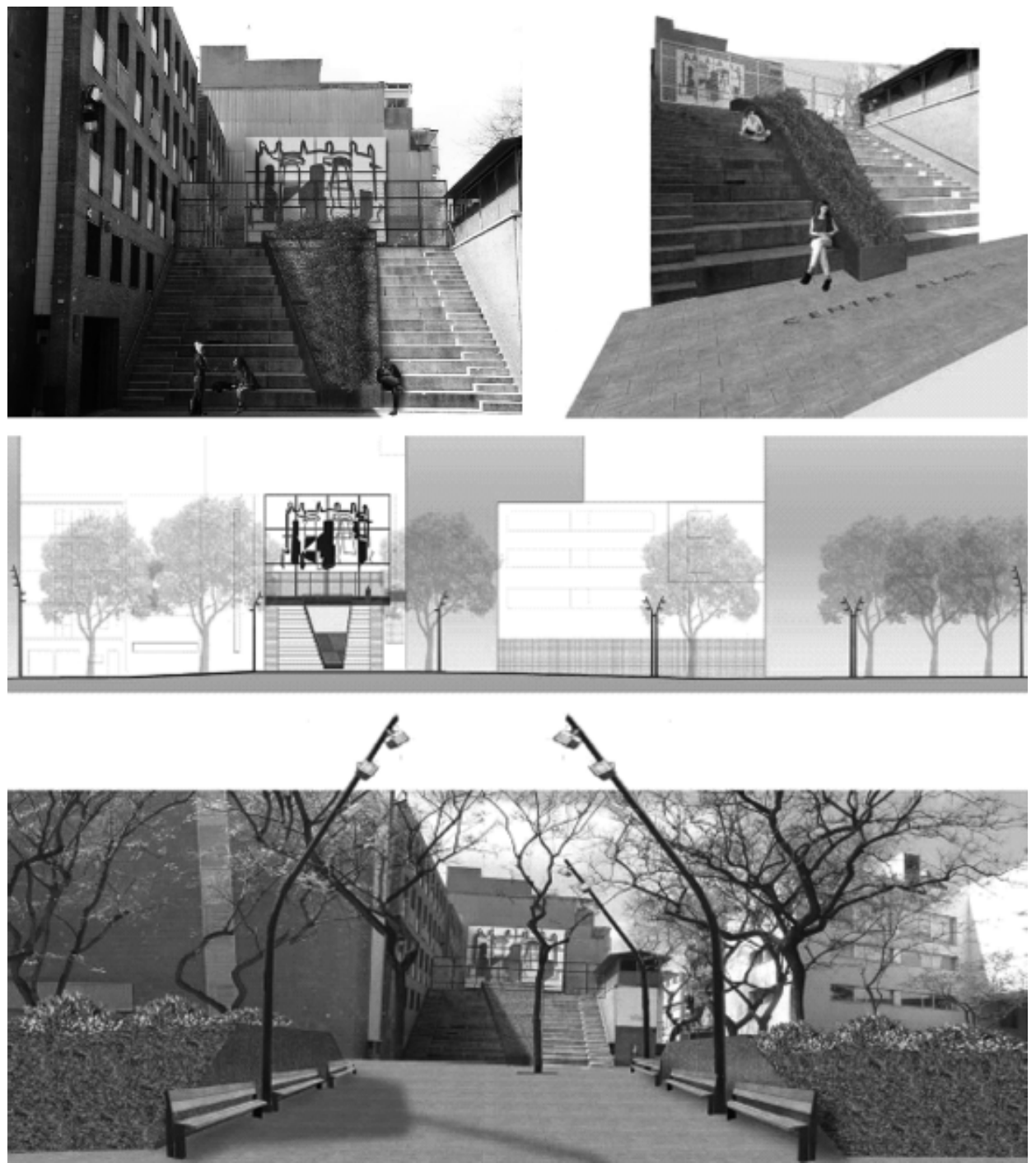

Fig. 55-58. Some renders of the re-design of the square and the Integration of the Remembrance Element, the White Centre. Source: Antoni Remesar, Bibiana Crespo-Martin. 


\section{To conclude}

The work we present is a first step in the development of the remembrance spatial system in Bon Pastor. It is an initial proposal which contains some valid arguments of art and urban design important for the development of this system once residents reach a consensus on the options for locations and forms of remembrance system. We can highlight the fact that we have found three unitary, non-unifying, systems that can allow the spatial unfolding of the Bon Pastor's Remembrance. The first one, once the stage of representation in trompe l'oeil has been overcome, introduces sculptural solutions that, in addition, can contribute to the improvement of the urban landscape in relation to the party-walls. The unitary treatment of the different sites or location of the system will help to create an integrated image of the system, using repetitive elements of the urban landscape in Barcelona (panot and directional signalling system), appropriately modified in the logic of this remembrance project, meaning thus, another step in the systemic image of the project. Thus, we avoid a recurrent error in many projects of this nature: the multiplication and dispersion of forms and expressive languages, which prevent, that such a system contributes to enhancing the service value of the public space. Regarding the urban design of the different sites, we cannot bet on a unitary solution, since the designs must respond to the characteristics of their surroundings. This work, especially when completed the participatory process, shows once again that the collaborative process between University, neighbours and local authorities, which is underdeveloped in Spain and is a good way, not only for the empowerment of citizens but also for the choice of the best options in the process of "city making."

\section{BIBLIOGRAPHY}

AA.VV. "Cohesión urbana. Mejorando la conectividad entre Baró de Viver y Bon Pastor." On theW@terfront 38 (2) (2015): 7-68.

Ascher, François. Los Nuevos Principios Del Urbanismo. Madrid: Alianza Editorial, 2001.

Barthes, Roland. El grado cero de la escritura. Buenos Aires: Jorge Álvarez, 1967.

Borja, Jordi and Zaida Muxí Martínez. L'espai públic: ciutat i ciutadanía. Barcelona: Diputació de Barcelona, 2001.

Borja, Jordi. Estado y Ciudad. Descentralización Política y Participación. Barcelona: PPU. Promociones y Publicaciones Universitarias, 1988.

- Luces y sombras del urbanismo de Barcelona. Barcelona: Universitat Oberta de Catalunya, 2009.

Brandão, Pedro. La imagen de la ciudad. Estrategias de Identidad y Comunicación. Barcelona: Publicacions i Edicions de la Universitat de Barcelona, 2011.

—. O Sentido da Cidade. Ensaios sobre o mito da Imagem como Arquitectura. Lisboa: Livros Horizonte, 2011.

Castells, Manuel. La cuestión Urbana. México: Siglo XXI Editores, 1972. 
Castells, Martínez Àngels. "De l'exercici de la sobirania nacional al principi de subsidiarietat." In La qüestió nacional, un debat obert, edited by Marcelo Céspedes. Barcelona: Fundació Pere Ardiaca, 1996: 19-44.

Checa-Artasu, Martín and Carme Trave. Bon pastor, La història d'un barri. Barcelona: Ajuntament de Barcelona, 2007.

Commission of European Communities, Third Report on Economic and Social Cohesion: A partnership for cohesion. Luxemburg: Publication service of European Union, 2004.

Domingo, Miquel and Ferran Sagarra. Barcelona. Les Cases Barates. Barcelona: Ajuntament de Barcelona, 1999.

Esparza Lozano, Dánae. El diseño del suelo: el papel del pavimento en la creación de la imagen de la ciudad. Barcelona: TDX. CAT, 2014. http://tdx.cat/handle/10803/146248.

Ferrer, Amador. Els Polígons de Barcelona. Barcelona: Edicions de la UPC, 1996.

Fuentes Milà, Sergio. L'esglèsia del Bon Pastor de Barcelona. Història, art i arquitectura. Barcelona: Ajuntament de Barcelona, 2015.

Gonçalves Brandão Estêvão, Ana Luísa. A incerteza no proceso urbano. A produção do espaço na Margem Sul do Estuário do Tejo. Barcelona: Universitat de Barcelona, 2015, http://tdx.cat/handle/10803/320178.

Hernando, Mateo and Nemo A. Remesar. "The 'Employment in the Neighbourhoods' project: A local economic development experience in Catalonia." Local Economy 6, 2011: 6-17.

Huertas, Josep Maria. "El fin del Mundo." In Baró de Viver: La Transformación de un barrio (1994-1999), edited by Genaro Villagrasa. Barcelona: CR POLIS. Universitat de Barcelona, 1999.

Iglesias, Borja M. and José Luis Oyón. Las barracas y la infravivienda en la construcción de Barcelona,1914-1950. Barracas. La Barcelona informal del siglo XX. Barcelona: Museu d'Història de Barcelona (MUHBA), 2010. http://docplayer.es/6991499-Las-barracas-y-lainfravivienda-en-la-construccion-de-barcelona-1914-1950-barracas-la-barcelona-informal-delsiglo-xx.html.

Lefebvre, Henry. La revolución urbana. Madrid: Alianza Editorial, 1973.

- La production de l'espace. Paris: Anthropos, 2000.

Padilla, Samuel. Producción de Espacio Público (X) Participación Ciudadana. El proyecto de espacio público resultado de procesos de participación ciudadana. Barcelona: CR POLIS. Universitat de Barcelona, 2015. http://tdx.cat/handle/10803/309288.

Pinto, Ana Júlia. Coesão urbana: o papel das redes de espaço público. Barcelona: CR POLIS. Universitat de Barcelona, 2015. http://hdl.handle.net/10803/320186.

Pinto, Ana Júlia and Antoni Remesar. "Public Space Networks as a Support for Urban Diversity." Open House International, 37, 2012: 15-24.

Portas, Nuno. Os tempos das formas. Vol. I. A cidade feita e refeita. Guimarães: Universidade do Minho, 2005.

Remesar, Antoni and Ángela Lúzia, Nas Margens/En los Márgenes. Bairro Amarelo, Baró de Viver. Barcelona: Universitat de Barcelona, 2013.

Remesar, Antoni and Xavier Salas, Samuel Padilla, Dánae Esparza. "Inclusion and empowerment in public art and urban design." On the W@terfront 24 (2012): 3-32.

Remesar, Antoni and Xavier Salas, Tomeu Vidal, "Urban Governance and Creative Participation in Public Space and Public Art." In The Art of Urban Design in Urban Regeneration, edited by Anntoni Remesar. Barcelona: Edicions de la Universitat de Barcelona, 2016: 112-156.

Remesar, Antoni and Xavier Salas, Tomeu Vidal, Bibiana Crespo, Roser Masip, Cohesión urbana. Construyendo la memoria (Baró de Viver - Bon Pastor. Dos exposiciones). Barcelona: CR POLIS. Universitat de Barcelona, 2016.

Remesar, Nemo A. "Employment, Social Cohesion and Territory. Integrating labour market policies into urban regeneration processes in Catalonia: The Employment in the 
Neighbourhoods case study." In The Art of Urban Design in Urban Regeneration, edited by Anntoni Remesar. Barcelona: Edicions de la Universitat de Barcelona, 2016: 27-61.

Salas, Xavier. L'artista com a facilitador en els processos de participació ciutadana: el cas Baró de Viver a Barcelona. Barcelona: Universitat de Barcelona, 2015.

_. "Bon Pastor (Barcelona). Un territorio en construcción." On the W@terfront 43 (2016): $7-46$.

Solà-Morales, Manuel. Les formes del creixement urbà. Barcelona: Edicions UPC, 1993.

Tatjer Mir, María Mercedes and Cristina Larrea-Killinger. Barraques. La Barcelona Informal del segle XX. Barcelona: Ajuntament de Barcelona, 2010.

Valera, Sergi. "Identidad y significado del espacio urbano desde una perspectiva psicosocioambiental. Nuevo espacio público y nuevos retos sociales," Arquitectonics 19-20 (2010): 125-136.

\section{Acknowledgements}

This work has been possible with the support of the project 2009SGR903 financed by the AGAUR of the Generalitat de Catalunya and the project PTDC/EC M-URB/2162/2014 financed by the Foundation for Science and Technology of Portugal and within the framework of the Collaboration agreement between the Ajuntament de Barcelona (Sant Andreu Disctrict), Bon Pastor's Association of Neighbours and the Polis Research Centre, Universitat de Barcelona. 